\title{
Conventional and Molecular Techniques from Simple Breeding to Speed Breeding in Crop Plants: Recent Advances and Future Outlook
}

\author{
Sunny Ahmar ${ }^{1,+}{ }^{,}$Rafaqat Ali Gill ${ }^{2, \dagger}$, Ki-Hong Jung ${ }^{3, *(\mathbb{C})}$, Aroosha Faheem ${ }^{4}$, \\ Muhammad Uzair Qasim ${ }^{1}$, Mustansar Mubeen ${ }^{5}$ and Weijun Zhou ${ }^{6, *}$ \\ 1 National Key Laboratory of Crop Genetic Improvement, College of Plant Science and Technology, \\ Huazhong Agricultural University, Wuhan 430070, Hubei, China; sunny.ahmar@yahoo.com (S.A.); \\ uzairqasim1149@yahoo.com (M.U.Q.) \\ 2 Oil Crops Research Institute, Chinese Academy of Agriculture Sciences, Wuhan 430070, China; \\ drragill@caas.cn \\ 3 Graduate School of Biotechnology \& Crop Biotech Institute, Kyung Hee University, Yongin 17104, Korea \\ 4 State Key Laboratory of Agricultural Microbiology and State Key Laboratory of Microbial Biosensor, \\ College of Life Sciences Huazhong Agriculture University, Wuhan 430070, China; \\ arushafaheem@hotmail.com \\ 5 State Key Laboratory of Agricultural Microbiology and Provincial Key Laboratory of Plant Pathology of \\ Hubei Province, College of Plant Science and Technology, Huazhong Agricultural University, Wuhan 430070, \\ China; mustansar01@yahoo.com \\ 6 Institute of Crop Science and Zhejiang Key Laboratory of Crop Germplasm, Zhejiang University, \\ Hangzhou 310058, China \\ * Correspondence: khjung2010@khu.ac.kr (K.-H.J.); wjzhou@zju.edu.cn (W.Z.) \\ + These authors contributed equally to this work.
}

Received: 8 February 2020; Accepted: 5 April 2020; Published: 8 April 2020

\begin{abstract}
In most crop breeding programs, the rate of yield increment is insufficient to cope with the increased food demand caused by a rapidly expanding global population. In plant breeding, the development of improved crop varieties is limited by the very long crop duration. Given the many phases of crossing, selection, and testing involved in the production of new plant varieties, it can take one or two decades to create a new cultivar. One possible way of alleviating food scarcity problems and increasing food security is to develop improved plant varieties rapidly. Traditional farming methods practiced since quite some time have decreased the genetic variability of crops. To improve agronomic traits associated with yield, quality, and resistance to biotic and abiotic stresses in crop plants, several conventional and molecular approaches have been used, including genetic selection, mutagenic breeding, somaclonal variations, whole-genome sequence-based approaches, physical maps, and functional genomic tools. However, recent advances in genome editing technology using programmable nucleases, clustered regularly interspaced short palindromic repeats (CRISPR), and CRISPR-associated (Cas) proteins have opened the door to a new plant breeding era. Therefore, to increase the efficiency of crop breeding, plant breeders and researchers around the world are using novel strategies such as speed breeding, genome editing tools, and high-throughput phenotyping. In this review, we summarize recent findings on several aspects of crop breeding to describe the evolution of plant breeding practices, from traditional to modern speed breeding combined with genome editing tools, which aim to produce crop generations with desired traits annually.
\end{abstract}

Keywords: food security; food scarcity; conventional breeding; CRISPR/Cas9; CRISPR/Cpf1; high-throughput phenotyping; speed breeding 


\section{Introduction}

Since the early 1900s, plant breeding has played a fundamental role in ensuring food security and safety and has had a profound impact on food production all over the world [1,2]. In recent years, however, problems related to food quality and quantity globally have arisen as a consequence of the excessive food requirement for the rapidly increasing human population. Furthermore, radical changes in weather conditions caused by global climate change are causing heat and drought stress; consequently, farmers around the world are facing significant yield losses [3]. Global epidemics, such as the Irish potato blight of the 1840s and the Southern corn leaf blight in the United States in the 1970s, were disastrous events leading to the deaths of millions of people due to food shortage $[4,5]$. In recent years, the ratio of food production to consumption has decreased considerably, while both urbanization rates and demographic growth have increased globally. In this era of fast development and rapid growth, people prefer to consume processed foods, where nutritional quality is compromised. The world is expected to reach 10 billion by 2050, but no satisfactory strategies are in place to feed this massive population [6,7]. Developed countries have increased their agricultural productivity, partially meeting their food requirements, but this has resulted in increased stress on food manufacturing departments [8].

Plant breeding can be used to develop plants with desired traits [9]. Artificial plant selection has been used by humans for the past 10,000 years, selecting and breeding plants with higher nutritional values [10] (Figure 1). Traditional agricultural methods aimed to improve the nutritional status of different food plants. Recent scientific developments provide a wide range of possibilities and innovations in plant breeding [11]. To satisfy the continuously increasing demand for plant-based products, the current level of annual yield enhancement in major crop species (varying from $0.8-1.2 \%$ ) must be doubled [12].

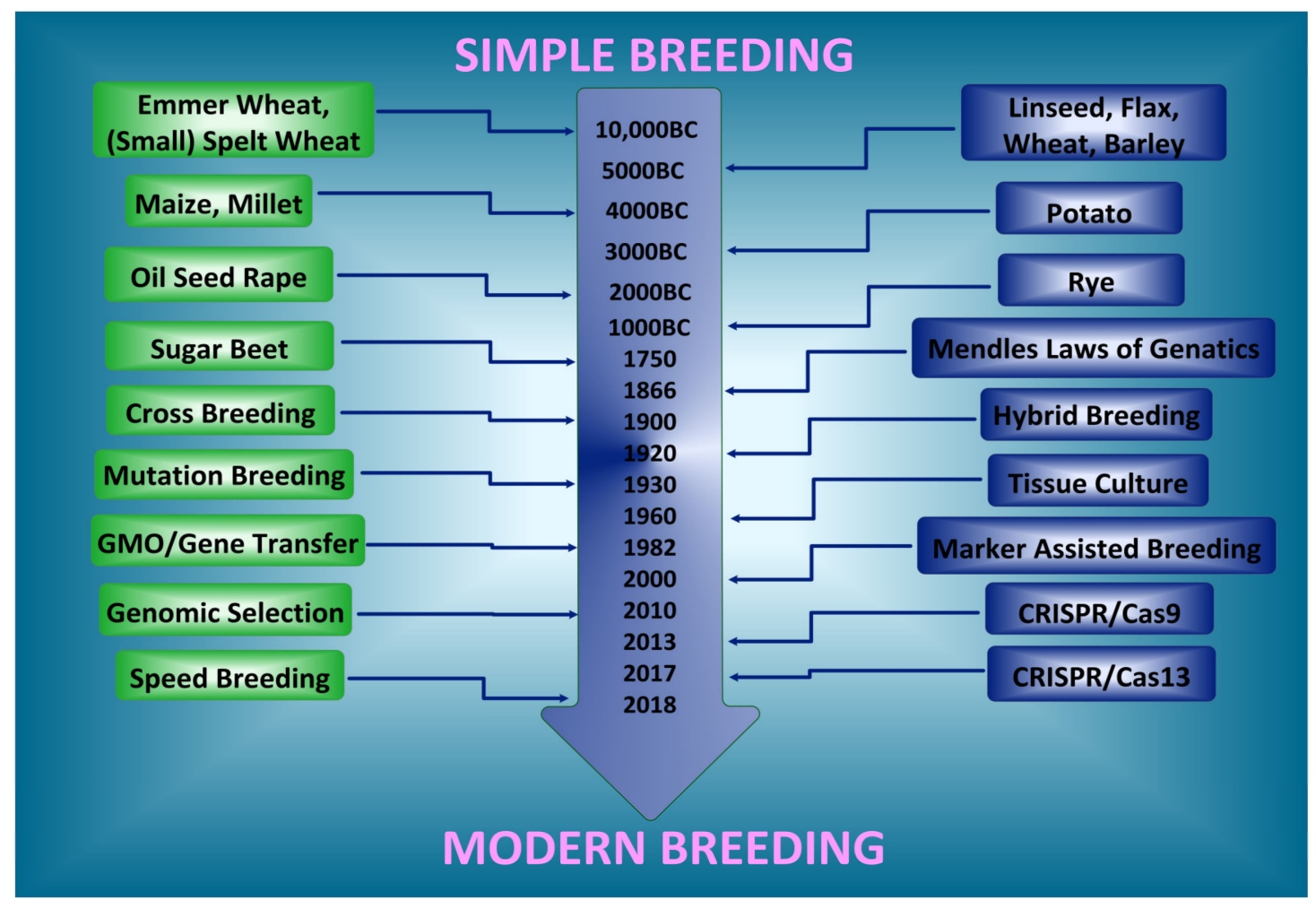

Figure 1. Historical milestones in plant breeding. For 10,000 years, farmers and breeders have been developing and improving crops. Presently, farmers feed 10 times more people using the same amount of land as 100 years ago. 
The introduction of Mendelian laws revolutionized the field of crop breeding. Over the last 150 years, crop development has been altered to a great extent as a consequence of contemporary cutting-edge genomics [13]. Different approaches have been used to shorten the duration of plant reproductive cycles. Novel techniques developed in this decade, such as genomic selection, high-throughput phenotyping (HTP), and modern speed breeding, have been shown to accelerate plant breeding. Genetic engineering and molecular methods have also played a role in developing crops with desirable characteristics using gene transformation [14-17]. Other techniques like large-scale sequencing, genomics, rapid gene isolation, and high-throughput molecular markers have also been proposed to improve the breeding of commercially important crop species, such as cisgenesis, intragenesis, polyploidy breeding, and mutation breeding [18-21].

Conventional breeding techniques are inadequate for plant genome enhancement to develop new plant varieties. To overcome this obstacle in plant breeding practices, molecular markers have been used since the 1990s for the selection of superior hybrid lines [22]. Improving plant phenotype for a specific desirable trait involves the artificial selection and breeding of this given trait by the plant breeder. Generally, breeders tend to focus on traits of diploid or diploid-like crops (e.g., maize and tomatoes) rather than polyploid crops (e.g., alfalfa and potatoes), which have more complex genetics. Breeders hence prefer to use crops with shorter reproductive cycles, which allow the production of several generations in a single year and, leading to faster production of the desired phenotypes by artificial breeding compared to crops that only reproduce annually or perennial plants that only reproduce every few years [23-25]. Plant breeding, combined with genome studies, enhances the accuracy of breeding practices and saves time [26]. Compared to other kingdoms, plants are more easily genetically manipulated to obtain desired genetic combinations by selfing, crossbreeding (or both) given their short generation time, and large population size available for analyses [27]. In the early 1980s, NASA partnered with Utah State University to explore the possibility of growing rapid cycling wheat under constant light in space stations. This joint effort resulted in the development of "USU-Apogee", a dwarf wheat line bred for rapid cycling [28,29]. Recently, Lee Hickey and colleagues solved this issue by presenting the idea of "speed breeding", a non-GMO path enabling researcher to turn over many generations and select plants for desired traits between many variations $[8,16]$. This method uses regulated environmental conditions and prolonged photoperiods to achieve between four and six generations per year of long duration crops (i.e., wheat, barley, and canola) $[16,30,31]$.

Researchers outlined the evolving EU regulatory framework for GMOs and discussed potential ways of regulating plant varieties developed using precision breeding approaches such as clustered regularly interspaced short palindromic repeats (CRISPR), and CRISPR-associated (Cas) proteins CRISPR/Cas9 [32]. Research interest in genetically engineered crops (and more precisely "biotech crops") has been increasing, given the urgent need to ensure food security for the growing human population [33].

Genome editing involves inserting, deleting, or substituting a foreign gene in the organism's DNA. Upon successful transformation, this new sequence is integrated into the host genome [34,35]. Several processes are involved in the fixation of specific DNA sequences, cut with the help of nucleases. Plant breeding alone cannot achieve the required traits, but using the CRISPR-associated (Cas) enzymes (CRISPR/Cas and CRISPR/Cpf1) can help meet the needs for efficient crop research [36,37]. In this review, we discuss the use of conventional and non-conventional plant breeding techniques for different crops, as well as the use of genome editing techniques to change and improve desired phenotypes. Moreover, the potential correlations between these approaches used to develop future strategies for crop improvement will also be explored.

\section{Mutation through Traditional or Conventional Breeding}

The advantage of conventional plant breeding consists of increasing the availability of genetic resources for crop improvement through introgression of the desired traits. However, some plants are at risk of becoming susceptible to environmental stress and losing genetic diversity [38]. Thus, 
traditional cultivation methods are not sufficient to resolve global food security issues. Combining multiple phenotypic characters within a single plant variety would successfully increase yield and has been widely used, however, new breeding techniques are less expensive and will enable faster production of genetically improved crops [39].

In recent times, improvements in traditional plant breeding have been introduced, such as wide crosses, introgression of traits from wild relatives by hybrid breeding, mutagenesis, double haploid technology, and some tissue culture-based approaches such as embryo and ovule rescue (to achieve maximum plant regeneration) and protoplast fusion [40-42]. Food and feed crops developed by conventional plant breeding have specific natural phenotypic and agronomic properties. To improve crop quality, researchers have introgressed many beneficial traits through plant breeding with wild relatives, such as higher yield, abiotic and biotic stress resistance, and increased nutritional value $[39,43,44]$. The identification and combination of traits in familiar genotypes and the selection of high-performing varieties can establish a crop lineage with the desired properties. That being said, this approach can have potentially adverse impacts on food and environmental safety as it occasionally gives rise to safety concerns through unpredictable effects [9,45].

A trait (e.g., stress tolerance) can be improved by selecting the best hybrid progeny with the desired trait using cross breeding [46] (Figure 2a). Desired traits can also be introduced into a chosen 'best' recipient line through backcrossing of the selected progeny with the recipient line for several generations to reduce unwanted phenotype combinations [47]. Genetic variability can be reduced by the use of long-term traditional breeding methods; thus, the introduction of new genes is required for the improvement of desired traits by speed breeding, mutation breeding, and rapid generation advance (RGA) [16,31,48]. From this point of view, mutations could be useful in plant breeding programs and all these precision breeding tools can contribute to the improvement of specific features during the breeding cycle. Plant breeding is always approached holistically by analyzing all applicable agricultural functionality (Figure 3).

A)

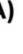

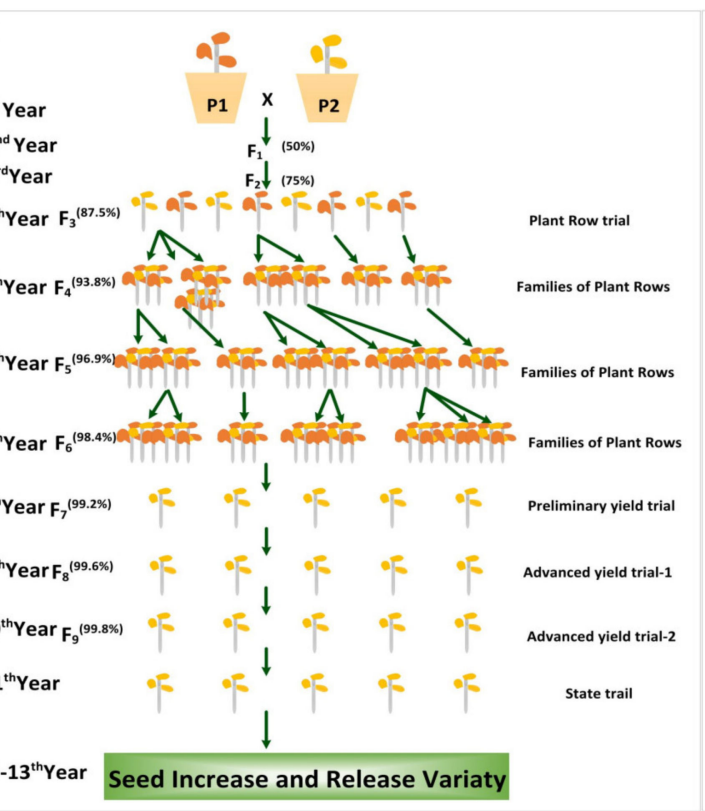

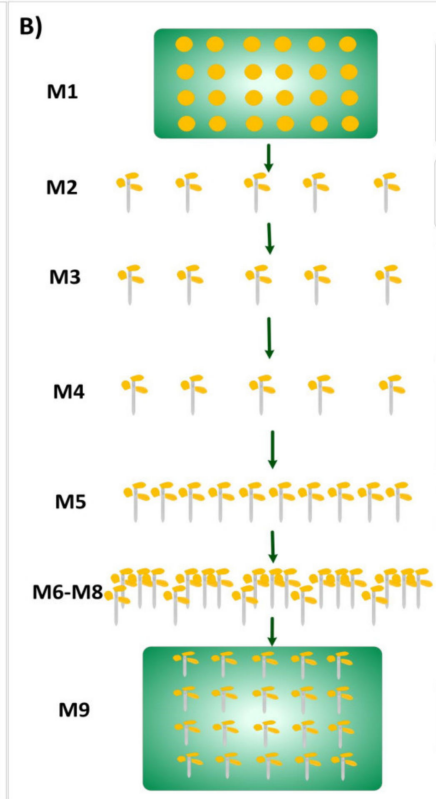

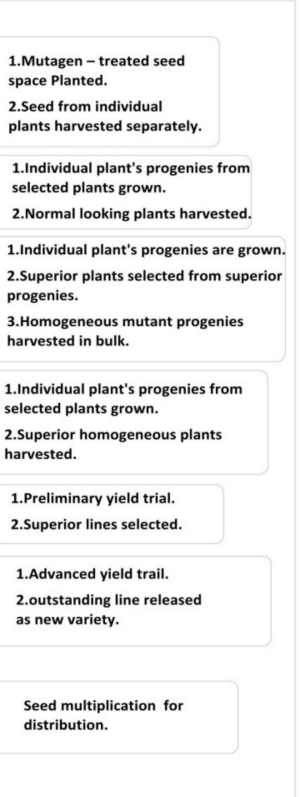

Figure 2. Improvement of agronomic traits using traditional breeding and chemical or physical mutagenic approaches. (A) Improving a trait (e.g., disease resistance) by the traditional breeding and for the introduction of the desired donor trait into the 'chosen' recipient line by selecting the progeny with the desired traits from the recipient line and crossing it with the donor line. (B) This process uses chemical or physical mutagens to generate mutants via random mutagenesis. 


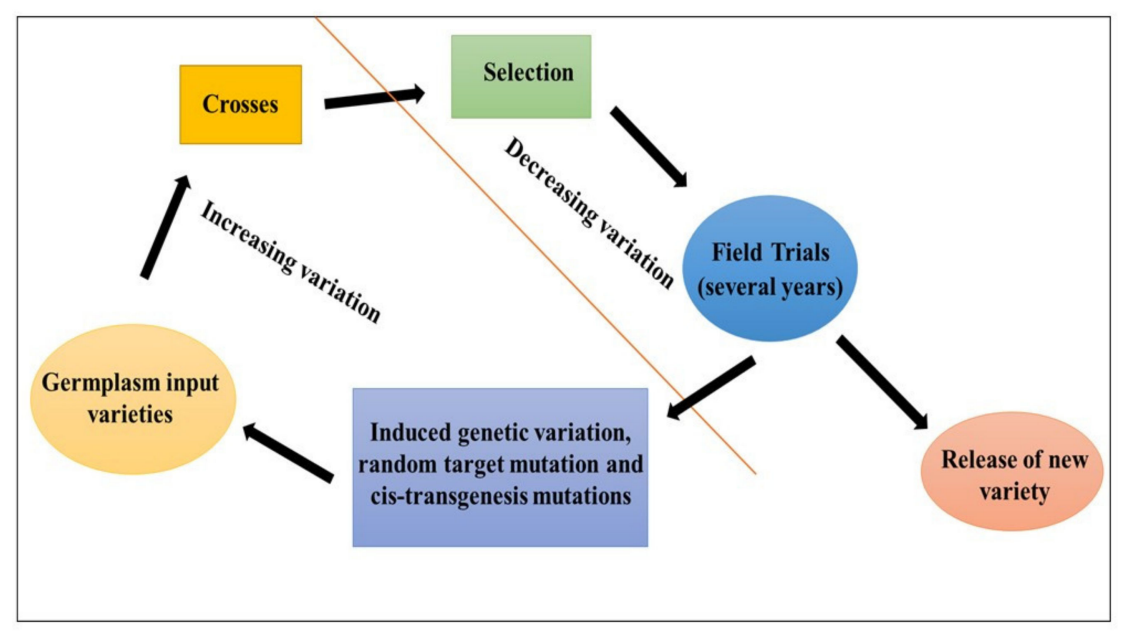

Figure 3. The plant breeding innovation cycle.

Identifying plants with desirable traits among existing plant varieties (or developing new phenotypes if these are not found naturally) is the initial and most important step in plant breeding. It would be impossible to develop new varieties or improve existing ones without natural genetic variation determined by spontaneous mutations. Ossowski et al. [49] concluded that the de novo spontaneous mutation rate was $7 \times 10^{-9}$ base replacements per site per generation in all the nuclear genomes of five Arabidopsis thaliana accumulation lines sustained by single seed descent (SSD) over 30 generations. [50]. This is expected to be true for the genomes of most other plant species: for example, about 20 billion mutations occur each year in a one-hectare wheat field (personal communication with Professor Detlef Weigel, Max Planck Institute for Developmental Biology, Germany).

Another technique to improve plant varieties by conventional breeding is through mutation breeding. Mutagenesis is the phenomenon in which sudden heritable changes occur in the genetic material of an organism. It can occur spontaneously in nature or can be a result of exposure to different chemical, physical, or biological agents [51]. Mutation breeding is classified based on the three known types of mutagenesis. The first is radiation-induced mutagenesis in which mutations occur as a result of exposure to radiation (gamma rays, $\mathrm{X}$-rays, or ion beams.); second is chemically induced mutagenesis; while the third is insertional mutagenesis, a consequence of DNA insertions either through the genetic transformation and insertion of T-DNA or the activation of transposable elements (i.e., site-directed mutagenesis; Table 1) [50,52]. According to Van Harten (Professor Agricultural University, Wageningen, The Netherlands), the history of plant mutation spans back to $300 \mathrm{BC}$, while the term mutation was first used in 1901 by Hugo De Vries, who reported during the final year of his studies that heredity might be changed by another mechanism, different from recombination and segregation [53]. He examined genomic variations and described them as heritable changes arising from this unique mechanism [54]. Numerous steps are required in any mutation breeding strategy: first, reducing the number of potential variants among the mutagenized seeds or other propagules for close evaluation of the first (M1) plant generation [51,54]. The benefits of mutation breeding over other breeding methods rely on the ability to select useful variant mutants in the second (M2) or third (M3) generations (Figure 2b).

Artificial mutation-causing agents are called mutagens; they are generally classified into two categories: physical and chemical mutagens [55]. They can induce mutations in almost any planting materials, including in vitro cultured cells, seedlings, and whole plants. Seeds are the most frequently used plant material for this specific purpose, but recently, various forms of plant propagules, such as tubers, bulbs, rhizomes, and mutation-induced vegetative propagated plants, are being used more frequently, as scientists take advantage of totipotency in single cells [56]. For example, with the use of ethyl methanesulfonate (EMS) and fast neutrons, collections of M82 tomato mutants were produced and more than 3000 phenotype alterations were classified [57]. An EMS-induced mutation library for 
the miniature dwarf tomato cultivar Micro-Tom has also been created, creating another resource for tomato genetic studies [58].

Table 1. Examples of commonly used physical and chemical mutagens, their characteristics, and hazard impacts.

\begin{tabular}{|c|c|c|c|c|}
\hline Types & Mutagens & Characteristics (Sources and Description) & Hazards & References \\
\hline & X-rays & $\begin{array}{l}\text { Electromagnetic radiation; penetrates tissues from just a few } \\
\text { millimeters to many centimeters. }\end{array}$ & $\begin{array}{l}\text { Dangerous, } \\
\text { penetrating }\end{array}$ & [59] \\
\hline & Gamma rays & $\begin{array}{l}60 \mathrm{Co}(\text { Cobalt-60) and 137Cs (Caesium-137); electric magnet } \\
\text { radiation generated with radiation isotope and nuclear reactors. }\end{array}$ & $\begin{array}{l}\text { Dangerous, } \\
\text { penetrating }\end{array}$ & {$[59,60]$} \\
\hline \multirow[t]{8}{*}{$\begin{array}{l}\text { Physical } \\
\text { Mutagens }\end{array}$} & Neutron & $\begin{array}{l}\text { 235U; there are fast, slow, thermal types; formed in nuclear reactors; } \\
\text { unloaded particles; penetrate tissues up to large } \\
\text { numbers centimeter; }\end{array}$ & $\begin{array}{c}\text { Very } \\
\text { dangerous }\end{array}$ & {$[59,60]$} \\
\hline & Beta particles & $\begin{array}{l}32 \mathrm{P} \text { and } 14 \mathrm{C} \text {; reduced particle accelerators or radioisotopes; } \\
\text { electrons; ionizing and penetrating tissues shallowly }\end{array}$ & $\begin{array}{c}\text { Maybe } \\
\text { dangerous }\end{array}$ & {$[60]$} \\
\hline & Alpha particles & $\begin{array}{l}\text { Sources originating from radiological isotopes; helium nucleus able } \\
\text { to penetrate tissues heavily }\end{array}$ & $\begin{array}{c}\text { Very } \\
\text { dangerous }\end{array}$ & [59] \\
\hline & Proton & $\begin{array}{l}\text { Present in nuclear reactors and accelerators; derived from the } \\
\text { nucleus of hydrogen; penetrate tissues up to several inches. }\end{array}$ & $\begin{array}{c}\text { Very } \\
\text { dangerous }\end{array}$ & {$[59,60]$} \\
\hline & Ion beam & $\begin{array}{l}\text { Positively charged ions are accelerated at a high speed and used to } \\
\text { irradiate living materials, including plant seeds and tissue culture. }\end{array}$ & Dangerous & {$[60]$} \\
\hline & Alkylating agents & $\begin{array}{l}\text { The alkylated base can then degrade with bases to create a primary } \\
\text { site which is mutagenic or recombinogenic or mispairs in DNA } \\
\text { replication mutations, depending on the atom concerned. }\end{array}$ & Dangerous & [59] \\
\hline & Azide & Just like alkylating agents. & Dangerous & [59] \\
\hline & Hydroxylamine & Just like alkylating agents. & Dangerous & {$[56,59]$} \\
\hline \multirow[t]{3}{*}{$\begin{array}{l}\text { Chemical } \\
\text { Mutagens }\end{array}$} & Nitrous acid & $\begin{array}{l}\text { Acts through deamination, replacing cytosine with uracil, which } \\
\text { can pair with adenine and thus result in transitions via subsequent } \\
\text { replication cycles. }\end{array}$ & Very Hazard & {$[56]$} \\
\hline & Acridines & $\begin{array}{l}\text { Interspersing between the DNA bases, thus distorting the DNA } \\
\text { double helix and the DNA polymerase, recognizes the new basis for } \\
\text { this expanded (intercalated) molecule and inserts a frameshift in } \\
\text { front of it. }\end{array}$ & Dangerous & [56] \\
\hline & Base analog & $\begin{array}{l}\text { Comprises the transformations (purine to purine and pyrimidine to } \\
\text { pyrimidine) into DNA in place of the regular bases during DNA } \\
\text { replication and tautomerizing (existent in two forms, which } \\
\text { interconvert into one another such that guanine may be present in } \\
\text { keto and enol forms). }\end{array}$ & $\begin{array}{l}\text { Some may be } \\
\text { dangerous }\end{array}$ & {$[56]$} \\
\hline
\end{tabular}

Despite considerable success during the last century, the advances in yields of major crops (e.g., wheat) stabilized or even declined in many regions of the world [61,62]. Restrictions on phenotyping efficiency are increasingly being perceived as key constraints to genetic enhancements in breeding practices $[63,64]$. Specifically, HTP may cause a bottleneck in traditional breeding, marker-assisted selection (MAS), or genomic selection, where phenotyping is important to establish the accuracy of statistical models $[63,65]$. Accurate phenotyping is also required to replicate the outcomes of mutagenesis (i.e., GMOs) [66]. Deery et al. [67] and White and Conley [68] reviewed in great detail the benefits and challenges of potential phenotyping platforms, such as HTP.

Furthermore, SSD can be accelerated through the use of HTP $[69,70]$. SSD is most suitable for handling large segregating populations; while HTP tools are used in breeding programs [71]. Without undermining genetic variability and genetic development, SSD optimizes resource distribution, reducing the time spent growing crops and lowering costs associated with earlier generations' progress [72]. SSD has been successfully used in the groundnut breeding program, with the implementation of an inbreeding cycle producing multiple generations annually to advance fixed lines to multisite evaluation tests [73]. This speed breeding approach is ideal for SSD programs, particularly in cereal crops, allowing for the rapid cycling of multiple lines with healthy plants and viable seeds [30]. 


\section{Mutagens for Molecular Breeding}

One of the principal goals in the field of molecular biology is to identify and manipulate genes involved in human, animal, and plant disorders. Genomic tools used in such studies include restriction enzymes, biomarkers, molecular glue (ligases), as well as transcription and post-translational modification machinery [74]. Furthermore, molecular biological approaches are widely used to develop biofortified crops and plant varieties with high yield, new traits, and resistance to insect pests and diseases $[75,76]$. Globally, about 40 million hectares have been assigned to transgenic cultivars, which were commercialized after testing their biosafety level in 1999 [75]. Plant breeding was then reformed when researchers started to combine traditional practices with molecular tools to address phenotypic changes concerning the genotype of plant traits [77]. Accurate genome sequencing is essential before molecular tools can be used, and next-generation sequencing (NGS) allows researchers to decipher entire genomes and produce vast gene libraries for bioinformatics studies [78]. NGS opens new possibilities in phylogenetic and evolutionary studies, enabling the discovery of novel regulatory sequences and molecular markers [79]. Molecular biology is also facilitating the identification of diverse cytoplasmic male sterility sources in hybrid breeding. Some fertility restorer genes have been cloned in maize, rice, and sorghum [80]. Mutations in the target gene can be screened using target-induced local lesions in the genome (TILLING) and Eco-TILLING, which can directly identify allelic variations in the genome [81]. The most recent studies have determined the structure of plant germplasm using bulked segregant analysis [82], association mapping, genome resequencing [83,84], and fine gene mapping. This allows for the identification of single base-pair polymorphisms based on single sequence repeats, single nucleotide polymorphisms (SNPs), and unique biomarkers linked to quantitative trait loci (QTL) for genome manipulation, germplasm enhancement, and creating high-density gene libraries [85]. Traditional mutagenesis has certain limitations, as it can produce undesirable knockout mutations. It is also time-consuming and requires large-scale screening [86]. However, MAS is a direct approach for tracking mutations that improve backcrossing efficiency (or "breeding by design") [87] and determining the homogeneity of the progeny phenotypes.

In principle, all genome cleavage techniques produce double-stranded breaks (DSBs), blunt ends, or overhangs of the target nucleotide fragment, whether by homologous recombination, site-directed insertion/substitution of genes, or knockout mutations [88]. These DSBs, produced as a result of the action of sequence-specific nucleases (SSNs), are repaired by the non-homologous end joining (NHEJ) mechanism, which adds or removes nucleotides by the homology-directed repair pathway, directing DNA substitutions at target sites [89]. Various literature reviews report three primary SSN systems for genome editing. The first involves zinc finger nucleases (ZFNs), which form the basis for DNA manipulation. The second system involves transcription activator-like effector nucleases (TALENs), while the third system, the most important revolution in cutting-edge genomics, is a clustered regularly interspaced short palindromic repeats/associated protein 9 (CRISPR/Cas9) system [88,90-92]. The use of ZFNs has certain limitations: the constructs are not easy to design and transform, even in plants, and it is an expensive approach. Moreover, some researchers have reported non-specific nucleotide recognition because of their origin from eukaryotic transcription motifs, making this approach less reliable for genome editing $[93,94]$. Most restriction nucleases are derived from bacteria and TALENs were isolated from the prokaryotic plant pathogen Xanthomonas [95]. However, TALENs comprise large and repetitive constructs that require a lot of time and precision to edit the target sequence [96]. Soon after the discovery of TALENs, another promising nuclease (CRISPR/Cas9) was found in a bacterial immune system [97]. This system has been widely used in recent plant genome editing studies and has started replacing the TALEN and ZFN systems due to its high efficiency and accuracy in inducing site-directed breaks in double-stranded DNA [98]. Recently, a CRISPR-associated endonuclease from Prevotella and Francisella (Cpf1) has emerged as a replacement tool for precise genome editing, including DNA-free dissection of plant material, with higher potency, specificity, and enormous possibilities of wider application $[99,100]$. The base-editing approach using CRISPR/nCas9 (Cas9 nickase) or dCas9 (deactivated Cas9) fused with cytidine deaminase is a powerful tool to create point mutations. In this 
study, we point out the remarkable G. hirsutum-base editor 3 (GhBE3) base enhancing system developed to create single base mutations in the allotetraploid genome of cotton (Gossypium hirsutum) [101].

\section{CRISPR/Cas9 and CRISPR/Cpf1 as Genetic Dissection Tools}

The CRISPR/Cas9 system is a high-throughput discovery system in cutting-edge genomics, with recent studies reporting extensive use of Cas9 in gene transformation, drug delivery, and knockout mutations based on NHEJ-mediated DSBs [102]. Several studies investigated the mode of action of this potent nuclease and discovered the presence of a CRISPR loci, a cluster of repeating nucleotides in bacterial and archaeal immune systems [103]. These loci have a unique sequence, comprising of Cas9-encoding operons, transcription machinery, and consecutive repeats originating from various viral genomes separated by spacer sequences. These repeats were incorporated into the bacterial genome either by a virus or another foreign invader following an immune reaction [17].

Yin et al. (2017) found that Cas9 can be 'tricked' by supplementing any foreign nucleotide sequence that is digested and inserted in the bacterial genome. To knock a gene out, the CRISPR/Cas9 system is designed accordingly and transformed to explants via Agrobacterium, electroporation or the biolistic method. The regenerated plantlets' grown from the transformed callus are then transferred to planting soil [104]. The CRISPR/Cas9 gene knockout system has four significant features: (a) synthetic guide RNA (about 18-20 nucleotides) binding to target DNA, (b) Cas9 cleavage at 3-4 nucleotides after the adjacent proto spacer motif (PAM) (generally, 50 NGG identifies the PAM sequence) [105], (c) selection of a suitable binary vector and sgRNA cloning, and (d) transforming the construct in explants via Agrobacterium or microprojectile gene bombardment (Figure 4). Agrobacterium-mediated transformation is preferred in most studies given its efficiency and secure delivery [106]. The transformants are raised in growth chambers and examined for mutation studies using PCR, western blotting, ELISA, genotyping, sequencing, and other molecular techniques.

With recent advances in molecular biology and the discovery of sequences in the microbial immune system, biotechnologists can manipulate the organism's genome in a specific and precise way with the aid of CRISPR and its associated Cas proteins. This remarkable genome editing technique is categorized into two broad classes and six types: class 1 with types I, III, and IV and class 2 with types II, type V, and type VI [107]. Type II is the most widely used system in genome editing, while CRISPR/Cas9 from the Streptococcus pyogenes is the most commonly used method in the genome editing process. CRISPR class II has a type V effector named Cpf1, which can be designed with highly specific CRISPR RNA to cleave corresponding DNA sequences [108,109]. Cpf1 was recently developed as a substitute to Cas9, because of its unique ability to target T-rich motives through staggered DSBs without the need to trans-activate crRNA. Cpf1 can also process RNA and the DNA nuclease operation. Studies have been conducted to examine the Cpf1 mechanism, aiming to achieve more precise DNA editing and to address it the crystal structure of Cas12b homologous [110]. Another study reported that small molecular compounds can enhance Cpf1 efficiency as they are directly involved in activating or suppressing signaling pathways for cellular repair. Thus, small-molecule-mediated DNA repair aids in useful CRISPR mediated knock-outs [111].

Unfortunately, the development of new crop varieties by genome editing has been delayed in many countries by strict GMO regulations across the globe. This is particularly true for areas obeying a process rather than a regulatory framework based on the product, like in the EU, where authorizations for new varieties developed by genome editing techniques are subject to time- and cost-intensive verification procedures [112]. A recent decision by the European Court of Justice announced the enforcement of strict GMO legislation on target genome editing tools, even if the product is entirely free of transgenes [113]. Process-based regulations were also introduced in at least 15 countries, such as Brazil, India, China, and Australia, while 14 countries, including Canada, Argentina, and the Philippines adopted a product-based regulation. Several countries still have no specific regulatory system in operation, including Paraguay, Myanmar, Chile, and Vietnam. One of the most interesting aspects of regulation is Argentina's adoption, which is more versatile as it allows recent developments 
in genome editing to be taken into account. In the EU, genome-edited plants are typically listed as GMOs in compliance with the current legislation [114]. The control of genetically modified (GM) crops in the United States is authorized on a case-by-case basis, as set out in the structured framework for the control of biotechnology [115].

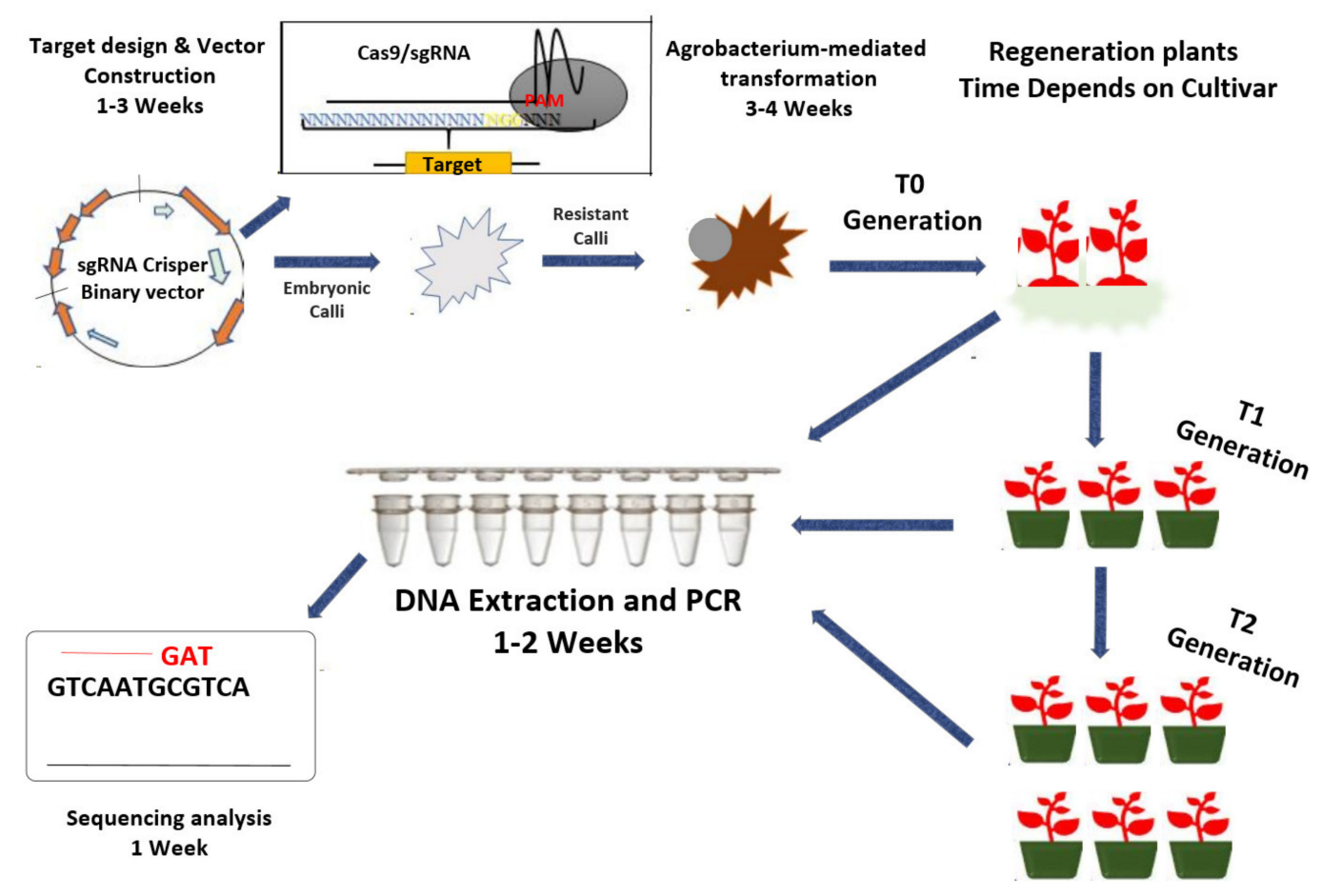

Figure 4. CRISPR-Cas9-based genome editing. CRISPR/Cas9 system uses Cas9 and sgRNA to cleave foreign DNA. It works in three steps: (1) the expression of the nuclear-localized Cas9 protein, (2) the generation of gRNA containing first 20-nt complementary to the target gene, and (3) the NGG PAM site recognition located nearly at the $3^{\prime}$ end of the target site. This process is followed by three additional steps: (1) design target and construction of a gene-specific sgRNA (vector), (2) CRISPR-Cas9 sgRNA can be transfected into the plant protoplast through Agrobacterium-mediated transformation, and (3) regenerated plants are screened for mutation via PCR-assay and sequencing. The estimated time needed is indicated for most steps.

\section{Speed Breeding (Time-Saving Tools) for Accelerating Plant Breeding}

Most plant species create a bottleneck in their applied research and breeding programs, generating the need for technologies to accelerate up plant growth and generation turnover. In the early 1980s, NASA's work was an inspiration for all plant scientists. In 2003, researchers at the University of Queensland coined the term "speed breeding" as a combination of methods developed to accelerate the speed of wheat breeding. Speed breeding protocols are currently being developed for several crops $[16,30]$. Speed breeding is suitable for diverse germplasm and does not require specific equipment for in vitro culturing, unlike doubled haploid (DH) technology, in which haploid embryos are produced to yield completely homozygous lines [116]. The principle behind speed breeding is to use optimum light intensity, temperature, and daytime length control $\left(22 \mathrm{~h}\right.$ light, $22^{\circ} \mathrm{C}$ day $/ 17^{\circ} \mathrm{C}$ night, and high light intensity) to increase the rate of photosynthesis, which directly stimulates early flowering, coupled with annual seed harvesting to shorten the generation time $[16,117]$. Light intensity and wavelength plays a key in the regulation of flowering [118,119]. Croser et al. [120] developed early- and late-flowering genotypes for peas, chickpeas, faba beans, and lupins under controlled conditions using various parts of the light spectrum (blue and far red-improved LED lights and metal halide). These species showed a positive correlation to the diminishing red:far red-red proportion (R:FR). Accordingly, light with the most elevated power in the FR area is the most inductive [121,122]. In general, light with high R:FR 
(e.g., from fluorescent lamps) reduces stem enlargement and increases lateral branching, whereas light with a low R:FR (e.g., from incandescent lamps) strongly enhances stem elongation but inhibits lateral branching and flowering. This process is regulated by FR, while blue light mediates phytochrome FR (Pfr). Furthermore, the effect of $\mathrm{R}$ light on flowering repression is mediated by phytochrome $\mathrm{R}$ (Pr) $[122,123]$.

Species-specific protocols to induce early flowering using certain environmental signals have been developed, such as short days or vernalization like RGA [48]. Greenhouse strategies under controlled conditions were compared with in vitro plus in vivo strategies and fast generation cycling by extended photoperiod [124-126]. The cost and space requirements associated with developing a large number of inbred lines can be reduced by implementing these practices in the breeding of small grain cereals grown at high densities (e.g., 1000 plants $/ \mathrm{m}^{2}$ ) [127].

Until recently, speed breeding had been reported to shorten generation time by extending photoperiods (Figure 5), while certain crop species, such as radish (Raphanus sativus), pepper (Capsicum annum), and leafy vegetables such as Amaranth (Amaranthus spp.) and sunflower (Helianthus annuus) responded positively to increased day length $[27,30,117,128]$. Speed breeding of short-day crops has been limited because of their flowering requirements. Nevertheless, recently, Lee Hickey and his research team worked on developing protocols for short-day crop like sorghum, millet and pigeon pea with the International Crop Research Institute for the Semi-Arid Tropics (ICRISAT) as part of a project funded by the Bill and Melinda Gates Foundation (https://geneticliteracyproject.org/2020/03/ 02/how-speed-breeding-will-help-us-expand-crop-diversity-to-feed-10-billion-people/). Sorghum, millet, and pigeon peas are important plants for many smallholder farmers in Africa and Asia, refining protocols targeted for these types of users has significant implications for global subsistence agriculture. This goal involves improving the protocols and conditions required for the induction of early flowering and rapid crop development [117]. O'Connor et al. (2014) already reported successful results in the speed breeding of peanuts (Arachis hypogaea). Increased day length helped amaranth (Amaranthus spp.) to achieve more generations annually [129]. In staple food crops requiring shorter photoperiods to initiate the reproductive phases, such as rice (Oryza sativa) and maize (Zea mays), speed breeding can accelerate vegetative growth [130]. Using speed breeding, it is possible to develop successive generations of improved crops for field examination via SSD, which is cheaper compared to the production of DHs. Speed breeding is also favorable to gene insertion (common haplotypes) of distinct phenotypes followed by MAS of elite hybrid lines [31,131].

In conclusion, recent advances in plant breeding and genomics have contributed to the development of qualitatively and quantitatively improved cultivars. Innovative agronomic strategies, in addition to the usual practices, have led to remarkable agricultural outcomes. However, sustainable crop development to ensure global food security can only be achieved with the combined investments of private firms, extension workers, and the public sector. 

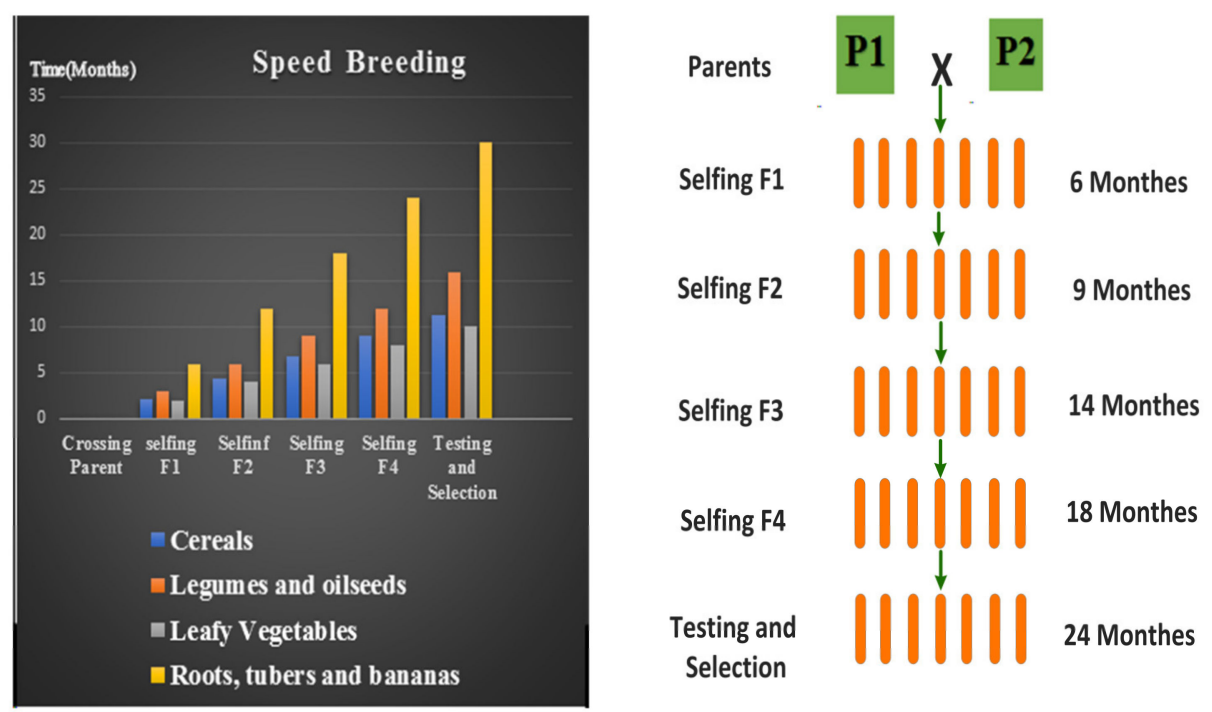

Figure 5. Graphical presentation of the elite line development procedure. Comparison of time (in months) required to develop elite lines from selected parents of some crops. Extended photoperiods induced earlier flowering and created 4 generations annually. The optimal temperature regime (maximum and minimum temperatures) should be applied for each crop. A higher temperature should be maintained during the photoperiod, whereas a fall in temperature during the dark period can aid in stress recovery. At the University of Queensland; (UQ), a $12-\mathrm{h} 22^{\circ} \mathrm{C} / 17^{\circ} \mathrm{C}$ temperature cycling regime with $2 \mathrm{~h}$ of darkness occurring within $12 \mathrm{~h}$ of $17^{\circ} \mathrm{C}$ has proven successful. The figure is briefly modified from Watson et al. (2018).

\section{Contribution of Plant Breeding to Crop Improvement}

Molecular plant breeding was revolutionized in the $21^{\text {st }}$ century, leading to crop improvement based on genomics, molecular marker selection, and conventional plant breeding practices [10,39]. For instance, the average yield of wheat (Triticum spp.), maize (Zea mays), and soybean (Glycine max), all significant crops in the United States, showed a positive linear increase from 1930 to 2012 [132,133]. The introduction of recessive genes in off-season nurseries was commercialized by pioneering plant breeder Norman Borlaug (among others), which helped to reduce the time needed to develop new cultivars. For example, the time for developing a new wheat cultivar was reduced from 10-12 years to only $5-6$ years [134].

In hybrid and pure line crop breeding, developing similar and homozygous lines is a time-consuming process. Cycle time has been reduced from five to two generations by producing homogeneous and homozygous lines using DHs in diverse crops $[135,136]$. The maize DH system is one of the most common, it uses the R1-NJ color marker. However, the DH system has various genotypic and biological limitations [136,137]. Different crop species show dependence on the genotype for haploid induction [138], adapting tissue culture (e.g., in case of anther culture), and chromosome doubling by colchicine [139]. Breeders using the DH system unintentionally practice many selections for loci, increasing the success rate of this approach [140], but this might limit genetic variation in the breeding populations in responsive genome regions. Another approach is the RNAi suppression of plant genes (for instance, the MutS HOMOLOG1 (MSH1) gene) in multiple plant species, which produces a variety of developmental modifications accompanied by adjustments in plant defense, phytohormones, and abiotic stress response pathways combined with methylome repatterning [141].

Although the evaluation and production of GM crops is an active area of research, this technology is currently restricted because of political and ethical concerns. Nevertheless, GMO technologies make use of the variations that are present in deliberately mutated or naturally occurring populations $[39,142,143]$. GMOs have a variety of practical applications, for instance, they can be used to produce plant proteins that are toxic to insect pests, create herbicide tolerance genes for weed control, and create "golden rice" 
biofortified with vitamin A [144]. The characterization and discovery of genes and promoters can offer precise and effective temporal and spatial control of the expression of different genes, which is crucial for the future use of GM crops [145].

The availability of published genome sequences for different crops is increasing every year, facilitated by the use of sequencing technologies that improve sequencing speed and cost $[146,147]$. Current sequencing technologies, such as the NGS technique, can sequence multiple cultivars with both small and large genomes at a reasonable cost [148]. Although various published genomes are considered to be incomplete, they remain a valuable tool to evaluate important crop traits such as grain traits, fruit ripening, and flowering time adaptation [83,149].

Modern plant breeding programs have engaged interdisciplinary teams with expertise in the fields of statistics, biochemistry, physiology, bioinformatics, molecular biology, agronomy, and economics [150]. Crop breeding has been revolutionized and research on the advancement of DNA sequencing technologies has started the "genomics era" of crop improvement [151]. The genomes of most of the essential crops have been sequenced, creating a much cheaper genotyping platform for DNA fingerprinting. SNPs are ubiquitous DNA markers in crop genomes, they are also cost-efficient and easy to handle. Therefore, in today's crop improvement practices, genotyping large populations with a large number of markers is standard practice. Even whole-genome resequencing data are becoming easily available, giving unprecedented access to the structural diversity of crop genomes [65,83,152].

Currently, researchers are also using molecular genetic mapping of QTL of many complex traits vital in plant breeding. The detection and molecular cloning of genes underlying QTL enable the investigation of naturally occurring allelic variations for specific complex traits $[85,153]$. Plant productivity can be improved by identifying novel alleles through functional genomics or haplotype analysis. Advances in cereal genomics research in recent years have enabled scientists to improve the prediction of phenotypes from genotypes in cereal breeding $[11,46]$.

Recently developed DNA-free CRISPR/Cas9 system delivery methods, different Cas9 variants, and RNA-guided nucleases offer new possibilities for crop genomic engineering [154]. The need to increase food security makes boosting crop production the primary objective of gene editing (Table 2). Crop yield is a complex trait that depends on several factors. The required phenotypes were found in plants with the loss of function mutations in yield related genes, highlighting the usefulness of CRISPR/Cas9 in improving yield-related traits by knocking out negative regulators affecting yield-determination factors, such as OsGS3 for grain size, OsGn1a for grain number; OsGW5, TaGW2, TaGASR7, and OsGLW2 for grain weight; TaDEP1 and OsDEP1 for panicle size, and OsAAP3 for tiller numbers. [155,156]. Similarly, three rice weight-related genes (GW5, GW2, and TGW6) were knocked out, causing pyramiding and increased weight [157]. The knockout of the Waxy gene using CRISPR/Cas9 resulted in the development of rice cultivars with higher nutritional quality [158]. DuPont Pioneer introduced a CRISPR/Cas9 knockout waxy corn line with high yields, ideal for commercial use [155]. A knockout of the MLO gene in tomato using CRISPR/Cas9 resulted in resistance to powdery mildew [159]. CRISPR has also been used to mutate the OsERF922 transcription factor, resulting in resistance to rice blast, a destructive fungal disease [160].

By adopting a $22 \mathrm{~h}$ photoperiod and a temperature-controlled regime, generation times were considerably reduced in durum wheat (T. durum), spring bread wheat (T. aestivum), chickpea (Cicer arietinum), pea (Pisum sativum), barley (Hordeum vulgare), stiff brome (Brachypodium distachyon), canola (Brassica napus), and barrel clover (Medicago truncatula), compared with plants grown in a greenhouse with no supplementary light or those grown in the field. Under rapid growth conditions, plant development was normal, plants (such as wheat and barley) could be crossed easily, and seed germination rates were high [31,161-163]. 
Table 2. Application of breeding techniques toward crop improvement.

\begin{tabular}{|c|c|c|c|c|}
\hline Sr.no. & Species & Method & Traits & References \\
\hline 1 & Rice & Cross Breeding & Increased spikelet number per panicle & [164] \\
\hline 2 & Rice & Cross Breeding & Yield Increases & [165] \\
\hline 3 & Wheat & Cross Breeding & Increase Grain Yield & [166] \\
\hline 4 & Tomato & Mutation Breeding & Resistance to bacterial wilt (Ralstonia solanacearum) & [167] \\
\hline 5 & Rapeseed & Mutation Breeding & Resistance to stem rot (Sclerotinia sclerotiorum) & [168] \\
\hline 6 & Cotton & Mutation Breeding & Resistance to bacterial blight, cotton leaf curl virus & [169] \\
\hline 7 & Barley & Mutation Breeding & Salinity tolerance & [170] \\
\hline 8 & Sunflower & Mutation Breeding & Semi-dwarf cultivar/dwarf & \\
\hline 9 & Cassava & Mutation Breeding & $\begin{array}{l}\text { High-amylose content preferred by diabetes patients } \\
\text { because it lowers the insulin level, which prevents quick } \\
\text { spikes in glucose contents. }\end{array}$ & [171] \\
\hline 10 & Groundnut & Mutation Breeding & $\begin{array}{l}\text { Dark green, obovate leaf pod; increased seed size, higher } \\
\text { yield, moderately resistant to diseases, increased oil and } \\
\text { protein content }\end{array}$ & [172] \\
\hline 11 & Maize & $\begin{array}{l}\text { Transgenic } \\
\text { Breeding }\end{array}$ & increased vitamin content (vitamins $\mathrm{C}, \mathrm{E}$, or provitamin $\mathrm{A}$ ) & [173] \\
\hline 12 & Tomato & $\begin{array}{l}\text { Transgenic } \\
\text { Breeding }\end{array}$ & Dry Matter Increases & {$[174]$} \\
\hline 13 & Soybean & $\begin{array}{l}\text { Transgenic } \\
\text { Breeding }\end{array}$ & Altered carbohydrates metabolism & [174] \\
\hline 14 & Barley & Molecular Marker & Adult resistance to stripe rust & [175] \\
\hline 15 & Maize & Molecular Marker & Development of quality protein maize & [22] \\
\hline 16 & Watermelon & $\begin{array}{l}\text { Marker-Assisted } \\
\text { Selection }\end{array}$ & Early Flowering & [176] \\
\hline 17 & Canola & QTL & Dynamic growth QTL & [153] \\
\hline 18 & Alfalfa & Intragenesis & Lignin content & [129] \\
\hline 19 & Apple & $\begin{array}{l}\text { Cisgenesis, } \\
\text { Intragenesis }\end{array}$ & Scab resistance & {$[177,178]$} \\
\hline 20 & Barley & Cisgenesis & Grain phytase activity & [179] \\
\hline 21 & Durum wheat & Cisgenesis & Baking quality & [180] \\
\hline 22 & Perennial ryegrass & Intragenesis & Drought tolerance & [181] \\
\hline 23 & Poplar & Cisgenesis & Plant growth and stature, wood properties & [181] \\
\hline 24 & Potato & Cisgenesis & Late blight resistance & [182] \\
\hline 25 & Strawberry & Intragenesis & Gray mold resistance & [183] \\
\hline 26 & Tomato & Gene editing/ZFN & $\begin{array}{l}\text { Reduction of cholesterol and steroidal glycoalkaloids, such } \\
\text { as toxic } \alpha \text {-solanine and } \alpha \text { - chaconine }\end{array}$ & [184] \\
\hline 27 & Wheat & $\begin{array}{c}\text { Gene } \\
\text { editing/TALEN }\end{array}$ & Heritable Modification & [185] \\
\hline 28 & Rice & $\begin{array}{l}\text { Gene knockout/ } \\
\text { CRISPR/Cas9 }\end{array}$ & Fragrance & [186] \\
\hline 29 & $\begin{array}{l}\text { Bread Wheat and } \\
\text { Maize }\end{array}$ & $\begin{array}{l}\text { Gene knockout/ } \\
\text { CRISPR/Cas9 }\end{array}$ & Leaf development; Male fertility, Herbicide resistance & [187] \\
\hline 30 & Poplar & $\begin{array}{l}\text { Gene knockout/ } \\
\text { CRISPR/Cas9 }\end{array}$ & Lignin content; Condensed tannin content & [188] \\
\hline 31 & Tomato & $\begin{array}{l}\text { Gene editing/ } \\
\text { CRISPR/Cas9 }\end{array}$ & Leaf development & [189] \\
\hline 32 & Soybean & $\begin{array}{c}\text { Gene replacement/ } \\
\text { CRISPR/Cas9 }\end{array}$ & Herbicide resistance & [190] \\
\hline 33 & Maize & $\begin{array}{c}\text { Gene replacement/ } \\
\text { CRISPR/Cas9 }\end{array}$ & Herbicide resistance & [187] \\
\hline 34 & Cotton & $\begin{array}{l}\text { Genome Editing/ } \\
\text { CRISPR/Cas9 }\end{array}$ & Produce transgenic seeds without regeneration & [191] \\
\hline 35 & Soybean & $\begin{array}{l}\text { Genome Editing/ } \\
\text { CRISPR/Cas9 }\end{array}$ & Early Flowering & [192] \\
\hline 36 & Rice & $\begin{array}{c}\text { Genome Editing/ } \\
\text { CRISPR/Cas9 }\end{array}$ & Increased grain weight & [157] \\
\hline 37 & Tomato & $\begin{array}{c}\text { Genome Editing/ } \\
\text { CRISPR/Cas9 }\end{array}$ & Resistance to powdery mildew & [159] \\
\hline 38 & Wheat & $\begin{array}{l}\text { Gene knockout/ } \\
\text { CRISPR/Cas9 }\end{array}$ & low-gluten foodstuff & [193] \\
\hline 39 & Rice & $\begin{array}{l}\text { Gene knockout/ } \\
\text { CRISPR/Cas9 }\end{array}$ & Generate mutant plants which is sensitive to salt stress & [194] \\
\hline 40 & Rapeseed & $\begin{array}{l}\text { Gene knockout/ } \\
\text { CRISPR/Cas9 }\end{array}$ & Controlling pod shattering resistance in oilseed rape & [195] \\
\hline 41 & Tomato, Potato & $\begin{array}{l}\text { CRISPR/Cas9 } \\
\text { Cytidine Base } \\
\text { Editor }\end{array}$ & $\begin{array}{l}\text { Transgene-free plants in the first generation in tomato and } \\
\text { potato }\end{array}$ & [196] \\
\hline 42 & Tobacco & $\begin{array}{l}\text { Genome Editing } \\
\text { /CRISPR/Cpf1 }\end{array}$ & Plants harboring & [197] \\
\hline 43 & Rice & $\begin{array}{l}\text { Genome Editing } \\
\text { /CRISPR/Cpf1 }\end{array}$ & Regulate the stomatal density in leaf & [198] \\
\hline 44 & Rice & $\begin{array}{l}\text { Genome Editing } \\
\text { /CRISPR/Cpf1 }\end{array}$ & Stable mRNA equal & {$[100,199]$} \\
\hline 45 & Maize & $\begin{array}{l}\text { Genome Editing } \\
\text { /CRISPR/Cpf1 }\end{array}$ & Mutation frequencies doubled & [199] \\
\hline
\end{tabular}


Table 2. Cont.

\begin{tabular}{|c|c|c|c|c|}
\hline Sr.no. & Species & Method & Traits & References \\
\hline 46 & Chickpea & $\begin{array}{l}\text { Rapid generation } \\
\text { advance (RGA) }\end{array}$ & Seven generations per year and enable speed breeding & [48] \\
\hline 47 & Pea & $\begin{array}{l}\text { Greenhouse } \\
\text { strategy }\end{array}$ & 6 Generation/year & [124] \\
\hline 48 & Chickpea & Speed Breeding & 4-6 Generation/year & [200] \\
\hline 49 & Barley & Speed Breeding & Resistance to Leaf Rust & [16] \\
\hline 50 & Spring wheat & Speed Breeding & Resistance to Stem Rust & [201] \\
\hline 51 & Spring wheat & Speed Breeding & 4-6 Generation/year & [16] \\
\hline 52 & Barley & Speed Breeding & 4-6 Generation/year & [16] \\
\hline 53 & Peanut & Speed Breeding & 2-3 Generation/year & [200] \\
\hline 54 & Canola & Speed Breeding & 4-6 Generation/year & [16] \\
\hline 55 & Wheat & $\begin{array}{l}\text { High-throughput } \\
\text { phenotyping (HTP) }\end{array}$ & Development of improved, high-yielding crop varieties & [202] \\
\hline 56 & Tomato & $\begin{array}{l}\text { High-throughput } \\
\text { phenotyping (HTP) }\end{array}$ & $\begin{array}{l}\text { Using biostimulants to increase the plant capacity of using } \\
\text { water }\end{array}$ & [203] \\
\hline
\end{tabular}

\section{Future Outlook}

Although modern plant breeding relies on traditional techniques, the emergence of new approaches will undoubtedly increase its efficiency and effectiveness. In the future, we can expect a wide range of techniques to be developed using interdisciplinary principles to increase their benefits. Strategies for crop production, breeding methods, approaches to field testing, genotyping technologies, even equipment and facilities need to be implemented across crop species to keep our food, fiber and biobased economy diverse. The discovery of CRISPR/Cas9, CRISPR/Cpf1, base-editing, and RGA has revolutionized molecular biology and its innovative applications in agriculture, setting a turning point in plant breeding and cultivation. GMOs can positively disseminate a selectable gene across wild populations in a gene drive process.

Altogether, CRISPR-based gene drive systems will prove-in time- to be beneficial for mankind. They will, for instance, prevent epidemics, improve agricultural practices, and control the spread of invasive species as plant cultivars resistant to insect pests and pathogens and tolerant to herbicides are developed. Existing genome editing techniques can be improved with the help of speed breeding (e.g., genes responsible for late flowering could be knocked out using CRISPR/Cas9). After the successful transfer of Cas9 into the plant, the transgenic plant can then be grown under speed breeding conditions rather than the usual glasshouse conditions to obtain transgenic seeds as early as possible. Using this method, it is possible to obtain stable homozygous phenotypes in less than a year. Furthermore, this method also decreases generation time, as it normally takes several years to develop a GMO crop. However, more efficient breeding strategies combining these technologies could lead to a step-change in the rate of genetic gain. Therefore, CRISPR/Cas9, primarily based on genome editing and speed breeding, will likely gain in popularity. It will be a crucial technique to obtain plants with specific desirable traits and contribute to reaching our objectives for zero-hunger globally. The development of innovations is often applied to a few important economic crops, which require specific adaptation to the reproduction and propagation method and the "process" of the new line development for the various crops of interest. Likewise, the transition of technology usually originates in developed countries, mostly in the private sector. It should be transferred to the public sector and into the developing world, given the significant financial investment required for groundbreaking work.

\section{Conclusions}

The primary methods for crop improvement in modern agriculture are cross breeding, mutation breeding, and transgenic breeding. Such time-consuming, laborious, and untargeted breeding programs cannot satisfy the increasing global food demand. To deal with this challenge and to enhance crop selection efficiency, marker-assisted breeding, and transgenic approaches have been adopted, generating desired traits via exogenous transformation into elite varieties. These genome editing systems are excellent tools that provide rapid, targeted mutagenesis and can identify the specific plant 
molecular mechanisms for crop improvement. Crop breeding was revolutionized by the development of next-generation breeding techniques. Genome editing technologies have many advantages over traditional agricultural methods, given their simplicity, efficiency, high specificity, and amenability to multiplexing. We conclude that speed breeding, combined with genetic tools and resources, enable plant biologists to scale up their research in the field of crop improvement.

Author Contributions: S.A., R.A.G., K.-H.J., and W.Z. designed the study; S.A., R.A.G., and M.U.Q. wrote the MS; S.A., A.F., M.M., R.A.G., W.Z., and K.H.J. revised the MS. In this study, S.A. and R.A.G. contributed equally. All authors have read and agreed to the published version of the manuscript.

Funding: This work was supported by the National Key Research and Development Program (2018YFD0100601), the National Natural Science Foundation of China (31650110476), the Jiangsu Collaborative Innovation Center for Modern Crop Production, the Sino-German Research Project (GZ 1362), the Science and Technology Department of Zhejiang Province (2016C02050-8), the Next-Generation Bio Green 21 Program (PJ01325901 and PJ01366401 to $\mathrm{KHJ}$ ), Republic of Korea, and the Collaborative Genome Program of the Korea Institute of Marine Science and Technology Promotion (KIMST) funded by the Ministry of Oceans and Fisheries (MOF) (No. 20180430 to JKH).

Acknowledgments: Authors are thankful to an anonymous reviewer for their comments and critical reading of the manuscript.

Conflicts of Interest: The authors declare that the research was conducted in the absence of any commercial or financial relationships that could be construed as a potential conflict of interest.

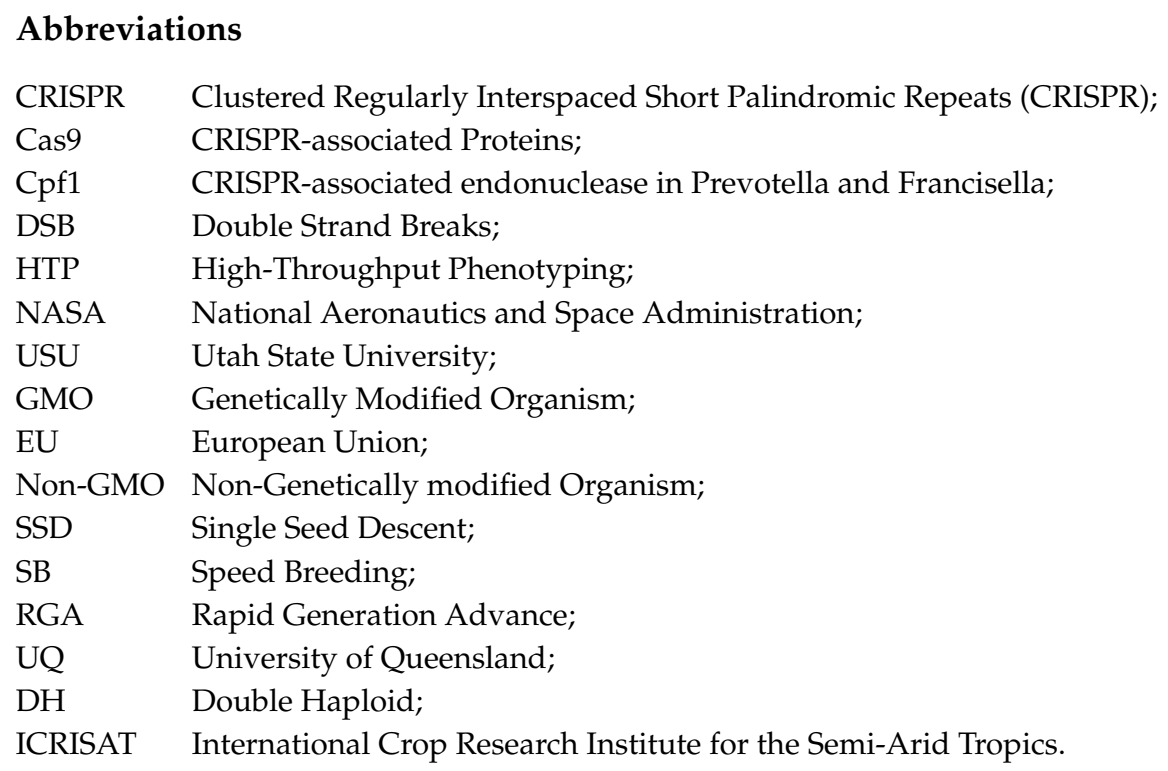

\section{References}

1. Tester, M.; Langridge, P. Breeding technologies to increase crop production in a changing world. Science (80-. ). 2010, 327, 818-822. [CrossRef] [PubMed]

2. Shiferaw, B.; Smale, M.; Braun, H.-J.; Duveiller, E.; Reynolds, M.; Muricho, G. Crops that feed the world 10. Past successes and future challenges to the role played by wheat in global food security. Food Secur. 2013, 5, 291-317. [CrossRef]

3. Von Braun, J.; Rosegrant, M.W.; Pandya-Lorch, R.; Cohen, M.J.; Cline, S.A.; Brown, M.A.; Bos, M.S. New Risks and Opportunities for Food Security Scenario Analyses for 2015 and 2050; IFPRI: Washington, DC, USA, 2005.

4. Ristaino, J.B. Tracking historic migrations of the Irish potato famine pathogen, Phytophthora infestans. Microbes Infect. 2002, 4, 1369-1377. [CrossRef]

5. Tatum, L.A. The Southern Corn Leaf Blight Epidemic. Science 1971, 171, 1113-1116. [CrossRef]

6. UN World Population Projected to Reach 9.8 Billion in 2050, and 11.2 Billion in 2100. Available online: https://www.un.org/development/desa/en/news/population/world-population-prospects-2017.html.

7. FAO How to Feed the World in 2050. In Insights from an Expert Meet; FAO: Roma, Italy, 2009; Volume 2050, pp. 1-35. 
8. Voss-Fels, K.P.; Stahl, A.; Hickey, L.T. Q\&A: Modern crop breeding for future food security. BMC Biol. 2019, $17,18$.

9. Cheema, K.S. K. Plant Breeding its Applications and Future Prospects. Int. J. Eng. Technol. Sci. Res. 2018, 5, $88-94$.

10. Moose, S.P.; Mumm, R.H. Molecular Plant Breeding as the Foundation for 21st Century Crop Improvement. Plant Physiol. 2008, 147, 969-977. [CrossRef]

11. Varshney, R.K.; Hoisington, D.A.; Tyagi, A.K. Advances in cereal genomics and applications in crop breeding. Trends Biotechnol. 2006, 24, 490-499. [CrossRef]

12. Li, H.; Rasheed, A.; Hickey, L.T.; He, Z. Fast-forwarding genetic gain. Trends Plant Sci. 2018, 23, $184-186$. [CrossRef] [PubMed]

13. Collins, F.S.; Green, E.D.; Guttmacher, A.E.; Guyer, M.S. A vision for the future of genomics research. Nature 2003, 431, 835-847.

14. Majid, A.; Parray, G.A.; Wani, S.H.; Kordostami, M.; Sofi, N.R.; Waza, S.A.; Shikari, A.B.; Gulzar, S. Genome Editing and its Necessity in Agriculture. Int. J. Curr. Microbiol. Appl. Sci. 2017, 6, 5435-5443. [CrossRef]

15. Araus, J.L.; Kefauver, S.C.; Zaman-Allah, M.; Olsen, M.S.; Cairns, J.E. Translating High-Throughput Phenotyping into Genetic Gain. Trends Plant Sci. 2018, 23, 451-466. [CrossRef] [PubMed]

16. Watson, A.; Ghosh, S.; Williams, M.J.; Cuddy, W.S.; Simmonds, J.; Rey, M.D.; Asyraf Md Hatta, M.; Hinchliffe, A.; Steed, A.; Reynolds, D.; et al. Speed breeding is a powerful tool to accelerate crop research and breeding. Nat. Plants 2018, 4, 23-29. [CrossRef] [PubMed]

17. Zhang, F.; Wen, Y.; Guo, X. CRISPR/Cas9 for genome editing: Progress, implications and challenges. Hum. Mol. Genet. 2014, 23, R40-R46. [CrossRef] [PubMed]

18. Murovec, J.; Pirc, Ž.; Yang, B. New variants of CRISPR RNA-guided genome editing enzymes. Plant Biotechnol. J. 2017, 15, 917-926. [CrossRef]

19. Acquaah, G. Polyploidy in Plant Breeding. In Principles of Plant Genetics and Breeding; John Wiley \& Sons: Hoboken, NJ, USA, 2012; pp. 452-469.

20. Muth, J.; Hartje, S.; Twyman, R.M.; Hofferbert, H.R.; Tacke, E.; Prüfer, D. Precision breeding for novel starch variants in potato. Plant Biotechnol. J. 2008, 6, 576-584. [CrossRef]

21. Mujjassim, N.E.; Mallik, M.; Rathod, N.K.K.; Nitesh, S.D. Cisgenesis and intragenesis a new tool for conventional plant breeding: A review. J. Pharmacogn. Phytochem. 2019, 8, 2485-2489.

22. Dreher, K.; Morris, M.; Khairallah, M.; Ribaut, J.M.; Shivaji, P.; Ganesan, S. Is marker-assisted selection cost-effective compared with conventional plant breeding methods? The case of quality protein Maize. Econ. Soc. Issues Agric. Biotechnol. 2009, 203-236.

23. Abreu, G.B.; Ramalho, M.A.P.; Toledo, F.H.R.B.; De Souza, J.C. Strategies to improve mass selection in maize. Maydica 2010, 55, 219-225.

24. Kandemir, N.; Saygili, İ. Apomixis: New horizons in plant breeding. Turkish J. Agric. For. 2015, 39, 549-556. [CrossRef]

25. Leifert, C.; Tamm, L.; Lammerts van Bueren, E.T.; Jones, S.S.; Murphy, K.M.; Myers, J.R.; Messmer, M.M. The need to breed crop varieties suitable for organic farming, using wheat, tomato and broccoli as examples: A review. NJAS - Wageningen J. Life Sci. 2011, 58, 193-205.

26. Doust, A.; Diao, X. Plant Genetics and Genomics: Crops and Models Volume 19. Genet. Genom. Setaria Ser. 2017, 19, 377.

27. Stetter, M.G.; Zeitler, L.; Steinhaus, A.; Kroener, K.; Biljecki, M.; Schmid, K.J. Crossing Methods and Cultivation Conditions for Rapid Production of Segregating Populations in Three Grain Amaranth Species. Front. Plant Sci. 2016, 7, 816. [CrossRef] [PubMed]

28. Bugbee, B.; Koerner, G. Yield comparisons and unique characteristics of the dwarf wheat cultivar "USU-Apogee". Adv. Sp. Res. 1997, 20, 1891-1894. [CrossRef]

29. Bula, R.J.; Morrow, R.C.; Tibbitts, T.W.; Barta, D.J.; Ignatius, R.W.; Martin, T.S. Light-emitting diodes as a radiation source for plants. HortScience 1991, 26, 203-205. [CrossRef]

30. Ghosh, S.; Watson, A.; Gonzalez-Navarro, O.E.; Ramirez-Gonzalez, R.H.; Yanes, L.; Mendoza-Suárez, M.; Simmonds, J.; Wells, R.; Rayner, T.; Green, P.; et al. Speed breeding in growth chambers and glasshouses for crop breeding and model plant research. Nat. Protoc. 2018, 13, 2944-2963. [CrossRef]

31. Hickey, L.T.; Germa, S.E.; Diaz, J.E.; Ziems, L.A.; Fowler, R.A.; Platz, G.J.; Franckowiak, J.D.; Dieters, M.J. Speed Breeding for Multiple Disease Resistance in Barley; Springer: New York, NY, USA, 2017. 
32. Chen, K.; Wang, Y.; Zhang, R.; Zhang, H.; Gao, C. CRISPR/Cas Genome Editing and Precision Plant Breeding in Agriculture. Annu. Rev. Plant Biol. 2019, 70, annurev. [CrossRef]

33. Godwin, I.D.; Rutkoski, J.; Varshney, R.K.; Hickey, L.T. Technological perspectives for plant breeding. Theor. Appl. Genet. 2019, 132, 555-557. [CrossRef]

34. Lee, J.; Chung, J.H.; Kim, H.M.; Kim, D.W.; Kim, H. Designed nucleases for targeted genome editing. Plant Biotechnol. J. 2016, 14, 448-462. [CrossRef] [PubMed]

35. Zhang, H.; Zhang, J.; Lang, Z.; Botella, J.R.; Zhu, J.K. Genome Editing-Principles and Applications for Functional Genomics Research and Crop Improvement. Crit. Rev. Plant Sci. 2017, 36, 291-309. [CrossRef]

36. Hsu, P.D.; Scott, D.A.; Weinstein, J.A.; Ran, F.A.; Konermann, S.; Agarwala, V.; Li, Y.; Fine, E.J.; Wu, X.; Shalem, O.; et al. DNA targeting specificity of RNA-guided Cas9 nucleases. Nat. Biotechnol. 2013, 3, 827. [CrossRef] [PubMed]

37. Zetsche, B.; Gootenberg, J.S.; Abudayyeh, O.O.; Slaymaker, I.M.; Makarova, K.S.; Essletzbichler, P.; Volz, S.E.; Joung, J.; Van Der Oost, J.; Regev, A.; et al. Cpf1 Is a Single RNA-Guided Endonuclease of a Class 2 CRISPR-Cas System. Cell 2015. [CrossRef]

38. Basey, A.C.; Fant, J.B.; Kramer, A.T. Producing native plant materials for restoration: 10 rules to collect and maintain genetic diversity. Nativ. Plants J. 2015, 16, 37-53. [CrossRef]

39. Krimsky, S. Traditional Plant Breeding. In GMOs Decoded; MIT Press: Cambridge, MA, USA, 2019.

40. Shepard, J.F.; Bidney, D.; Barsby, T.; Kemble, R. Fusion of Protoplasts. Biotechnol. Biol. Front. 2019.

41. Marthe, F. Tissue culture approaches in relation to medicinal plant improvement. In Biotechnologies of Crop Improvement; Research Gate: Berlin, Germany, 2018; Volume 1, pp. 487-497. ISBN 9783319782836.

42. Germana, M.A. Anther culture for haploid and doubled haploid production. Plant Cell Tissue Organ Cult. 2011, 104, 283-300. [CrossRef]

43. Hajjar, R.; Hodgkin, T. The use of wild relatives in crop improvement: A survey of developments over the last 20 years. Euphytica 2007, 156, 1-13. [CrossRef]

44. Ceccarelli, S.; Guimaraes, E.P.; Weltzien, E. Plant breeding and farmer participation; NHBS: Devon, UK, 2009; ISBN 9789251063828.

45. Cellini, F.; Chesson, A.; Colquhoun, I.; Constable, A.; Davies, H.V.; Engel, K.H.; Gatehouse, A.M.R.; Kärenlampi, S.; Kok, E.J.; Leguay, J.-J. Unintended effects and their detection in genetically modified crops. Food Chem. Toxicol. 2004, 42, 1089-1125. [CrossRef]

46. Dolferus, R.; Ji, X.; Richards, R.A. Abiotic stress and control of grain number in cereals. Plant Sci. 2011, 181, 331-341. [CrossRef]

47. Caligari, P.D.S.; Brown, J. Plant Breeding, Practice. In Encyclopedia of Applied Plant Sciences; Academic Press: Cambridge, MA, USA, 2016; Volume 2, pp. 229-235. ISBN 9780123948083.

48. Samineni, S.; Sen, M.; Sajja, S.B.; Gaur, P.M. Rapid generation advance (RGA) in chickpea to produce up to seven generations per year and enable speed breeding. Crop J. 2019. [CrossRef]

49. Ossowski, S.; Schneeberger, K.; Lucas-Lledó, J.I.; Warthmann, N.; Clark, R.M.; Shaw, R.G.; Weigel, D.; Lynch, M. The rate and molecular spectrum of spontaneous mutations in Arabidopsis thaliana. Science (80-. ). 2010, 327, 92-94. [CrossRef] [PubMed]

50. Oladosu, Y.; Rafii, M.Y.; Abdullah, N.; Hussin, G.; Ramli, A.; Rahim, H.A.; Miah, G.; Usman, M. Principle and application of plant mutagenesis in crop improvement: A review. Biotechnol. Biotechnol. Equip. 2016, 30, 1-16. [CrossRef]

51. Roychowdhury, R.; Tah, J. Mutagenesis-A potential approach for crop improvement. In Crop Improvement; Springer: New York, NY, USA, 2013; pp. 149-187.

52. Forster, B.P.; Shu, Q.Y.; Nakagawa, H. Plant mutagenesis in crop improvement: Basic terms and applications. Plant Mutat. Breed. Biotechnol. 2012, 9-20.

53. Van Harten, A.M. Mutation Breeding: Theory and Practical Applications; Cambridge University Press: Cambridge, MA, USA, 1998; ISBN 0521470749.

54. Kharkwal, M.C. A brief history of plant mutagenesis. Plant Mutat. Breed. Biotechnol. 2012, 21-30.

55. Mba, C.; Afza, R.; Bado, S.; Jain, S.M. Induced Mutagenesis in Plants. Plant Cell Cult. Essent. Methods 2010, 111-130.

56. Mba, C. Induced Mutations Unleash the Potentials of Plant Genetic Resources for Food and Agriculture. Agronomy 2013, 3, 200-231. [CrossRef] 
57. Menda, N.; Semel, Y.; Peled, D.; Eshed, Y.; Zamir, D. In silico screening of a saturated mutation library of tomato. Plant J. 2004, 38, 861-872. [CrossRef]

58. Watanabe, S.; Mizoguchi, T.; Aoki, K.; Kubo, Y.; Mori, H.; Imanishi, S.; Yamazaki, Y.; Shibata, D.; Ezura, H. Ethylmethanesulfonate (EMS) mutagenesis of Solanum lycopersicum cv. Micro-Tom for large-scale mutant screens. Plant Biotechnol. 2007, 24, 33-38. [CrossRef]

59. Wani, M.R.; Kozgar, M.I.; Tomlekova, N.; Khan, S.; Kazi, A.G.; Sheikh, S.A.; Ahmad, P. Mutation breeding: A novel technique for genetic improvement of pulse crops particularly Chickpea (Cicer arietinum L.). In Improvement of Crops in the Era of Climatic Changes; Springer: New York, NY, USA, 2014; pp. 217-248.

60. Mba, C.; Afza, R.; Shu, Q.Y.; Forster, B.P.; Nakagawa, H. Mutagenic radiations: X-rays, ionizing particles and ultraviolet. Plant Mutat. Breed. Biotechnol. 2012, 83-90.

61. Acreche, M.M.; Briceño-Félix, G.; Sánchez, J.A.M.; Slafer, G.A. Physiological bases of genetic gains in Mediterranean bread wheat yield in Spain. Eur. J. Agron. 2008, 28, 162-170. [CrossRef]

62. Sadras, V.O.; Lawson, C. Genetic gain in yield and associated changes in phenotype, trait plasticity and competitive ability of South Australian wheat varieties released between 1958 and 2007. Crop Pasture Sci. 2011, 62, 533-549. [CrossRef]

63. Araus, J.L.; Cairns, J.E. Field high-throughput phenotyping: The new crop breeding frontier. Trends Plant Sci. 2014, 19, 52-61. [CrossRef] [PubMed]

64. Tardieu, F.; Cabrera-Bosquet, L.; Pridmore, T.; Bennett, M. Plant Phenomics, From Sensors to Knowledge. Curr. Biol. 2017, 27, R770-R783. [CrossRef] [PubMed]

65. Crossa, J.; Pérez, P.; de los Campos, G.; Mahuku, G.; Dreisigacker, S.; Magorokosho, C. Genomic selection and prediction in plant breeding. J. Crop Improv. 2011, 25, 239-261. [CrossRef]

66. Blum, A. Genomics for drought resistance-getting down to earth. In Functional Plant Biology; CSIRO Publishing: Melbourne, Australia, 2014; Volume 41, pp. 1191-1198.

67. Deery, D.; Jimenez-Berni, J.; Jones, H.; Sirault, X.; Furbank, R. Proximal remote sensing buggies and potential applications for field-based phenotyping. Agronomy 2014, 4, 349-379. [CrossRef]

68. White, J.W.; Conley, M.M. A flexible, low-cost cart for proximal sensing. Crop Sci. 2013, 53, 1646-1649. [CrossRef]

69. Saxena, K.; Saxena, R.K.; Varshney, R.K. Use of immature seed germination and single seed descent for rapid genetic gains in pigeonpea. Plant Breed. 2017, 136, 954-957. [CrossRef]

70. Shakoor, N.; Lee, S.; Mockler, T.C. High throughput phenotyping to accelerate crop breeding and monitoring of diseases in the field. Curr. Opin. Plant Biol. 2017, 38, 184-192. [CrossRef]

71. Janila, P.; Variath, M.T.; Pandey, M.K.; Desmae, H.; Motagi, B.N.; Okori, P.; Manohar, S.S.; Rathnakumar, A.L.; Radhakrishnan, T.; Liao, B.; et al. Genomic tools in groundnut breeding program: Status and perspectives. Front. Plant Sci. 2016, 7. [CrossRef]

72. Sarutayophat, T.; Nualsri, C. The efficiency of pedigree and single seed descent selections for yield improvement at generation 4 (F4) of two yardlong bean populations. Kasetsart J. Nat. Sci. 2010, 44, 343-352.

73. Holbrook, C.C.; Timper, P.; Culbreath, A.K.; Kvien, C.K. Registration of “Tifguard" Peanut. J. Plant Regist. 2008, 2, 92. [CrossRef]

74. Huang, X. From Genetic Mapping to Molecular Breeding: Genomics Have Paved the Highway. Mol. Plant 2016. [CrossRef] [PubMed]

75. Jung, C. Chapter 3 Molecular Tools for Plant Breeding; Springer: New York, NY, USA, 2000; pp. 25-37.

76. Schaart, J.G.; van de Wiel, C.C.M.; Lotz, L.A.P.; Smulders, M.J.M. Opportunities for Products of New Plant Breeding Techniques. Trends Plant Sci. 2016. [CrossRef] [PubMed]

77. Vilanova, S.; Cañizares, J.; Pascual, L.; Blanca, J.M.; Díez, M.J.; Prohens, J.; Picó, B. Application of Genomic Tools in Plant Breeding. Curr. Genomics 2012, 13, 179-195.

78. Wendler, N.; Mascher, M.; Nöh, C.; Himmelbach, A.; Scholz, U.; Ruge-Wehling, B.; Stein, N. Unlocking the secondary gene-pool of barley with next-generation sequencing. Plant Biotechnol. J. 2014, 12, 1122-1131. [CrossRef]

79. Metzker, M.L. Sequencing technologies-The next generation. Nat. Rev. Genet. 2010, 11, 31. [CrossRef]

80. Dwivedi, S.; Perotti, E.; Ortiz, R. Towards molecular breeding of reproductive traits in cereal crops. Plant Biotechnol. J. 2008, 6, 529-559. [CrossRef]

81. Wang, T.L.; Uauy, C.; Robson, F.; Till, B. TILLING in extremis. Plant Biotechnol. J. 2012, 10, 761-772. [CrossRef] 
82. Zou, C.; Wang, P.; Xu, Y. Bulked sample analysis in genetics, genomics and crop improvement. Plant Biotechnol. J. 2016, 14, 1941-1955. [CrossRef]

83. Bolger, M.E.; Weisshaar, B.; Scholz, U.; Stein, N.; Usadel, B.; Mayer, K.F.X. Plant genome sequencingApplications for crop improvement. Curr. Opin. Biotechnol. 2014, 26, 31-37. [CrossRef] [PubMed]

84. Edwards, D.; Batley, J. Plant genome sequencing: Applications for crop improvement. Plant Biotechnol. J. 2010, 8, 2-9. [CrossRef] [PubMed]

85. Dhingani, R.M.; Umrania, V.V.; Tomar, R.S.; Parakhia, M.V.; Golakiya, B. Introduction to QTL mapping in plants. Ann. Plant Sci 2015, 4, 1072-1079.

86. McCallum, C.M.; Comai, L.; Greene, E.A.; Henikoff, S. Targeted screening for induced mutations. Nat. Biotechnol. 2000, 18, 455. [CrossRef] [PubMed]

87. Nadeem, M.A.; Nawaz, M.A.; Shahid, M.Q.; Doğan, Y.; Comertpay, G.; Yıldız, M.; Hatipoğlu, R.; Ahmad, F.; Alsaleh, A.; Labhane, N.; et al. DNA molecular markers in plant breeding: Current status and recent advancements in genomic selection and genome editing. Biotechnol. Biotechnol. Equip. 2018, 32, 261-285. [CrossRef]

88. Lloyd, A.; Plaisier, C.L.; Carroll, D.; Drews, G.N. Targeted mutagenesis using zinc-finger nucleases in Arabidopsis. Proc. Natl. Acad. Sci. USA 2005. [CrossRef]

89. Symington, L.S.; Gautier, J. Double-strand break end resection and repair pathway choice. Annu. Rev. Genet. 2011, 45, 247-271. [CrossRef]

90. Wood, A.J.; Lo, T.W.; Zeitler, B.; Pickle, C.S.; Ralston, E.J.; Lee, A.H.; Amora, R.; Miller, J.C.; Leung, E.; Meng, X.; et al. Targeted genome editing across species using ZFNs and TALENs. Science 2011, 333, 307. [CrossRef]

91. Sprink, T.; Metje, J.; Hartung, F. Plant genome editing by novel tools: TALEN and other sequence specific nucleases. Curr. Opin. Biotechnol. 2015. [CrossRef]

92. Mao, Y.; Zhang, H.; Xu, N.; Zhang, B.; Gou, F.; Zhu, J.K. Application of the CRISPR-Cas system for efficient genome engineering in plants. Mol. Plant 2013. [CrossRef]

93. Schneider, K.; Schiermeyer, A.; Dolls, A.; Koch, N.; Herwartz, D.; Kirchhoff, J.; Fischer, R.; Russell, S.M.; Cao, Z.; Corbin, D.R. Targeted gene exchange in plant cells mediated by a zinc finger nuclease double cut. Plant Biotechnol. J. 2016, 14, 1151-1160. [CrossRef] [PubMed]

94. De Pater, S.; Pinas, J.E.; Hooykaas, P.J.J.; van der Zaal, B.J. ZFN-mediated gene targeting of the Arabidopsis protoporphyrinogen oxidase gene through Agrobacterium-mediated floral dip transformation. Plant Biotechnol. J. 2013, 11, 510-515. [CrossRef] [PubMed]

95. Li, T.; Huang, S.; Jiang, W.Z.; Wright, D.; Spalding, M.H.; Weeks, D.P.; Yang, B. TAL nucleases (TALNs): Hybrid proteins composed of TAL effectors and FokI DNA-cleavage domain. Nucleic Acids Res. 2010, 39, 359-372. [CrossRef] [PubMed]

96. Char, S.N.; Unger-Wallace, E.; Frame, B.; Briggs, S.A.; Main, M.; Spalding, M.H.; Vollbrecht, E.; Wang, K.; Yang, B. Heritable site-specific mutagenesis using TALENs in maize. Plant Biotechnol. J. 2015, 13, 1002-1010. [CrossRef]

97. Mahfouz, M.M.; Piatek, A.; Stewart, C.N. Genome engineering via TALENs and CRISPR/Cas9 systems: Challenges and perspectives. Plant Biotechnol. J. 2014, 12, 1006-1014. [CrossRef]

98. Zhang, Y.; Xie, X.; Liu, Y.G.; Zhang, Y.; Xie, X.; Liu, Y.G.; Ma, X. CRISPR/Cas9-Based Genome Editing in Plants, 1st ed; Elsevier Inc.: Amsterdam, The Netherlands, 2017; Volume 149.

99. Zaidi, S.S.-e.-A.; Mahfouz, M.M.; Mansoor, S. CRISPR-Cpf1: A New Tool for Plant Genome Editing. Trends Plant Sci. 2017, 22, 550-553. [CrossRef]

100. Li, S.; Zhang, X.; Wang, W.; Guo, X.; Wu, Z.; Du, W.; Zhao, Y.; Xia, L. Expanding the scope of CRISPR/Cpf1-mediated genome editing in rice. Mol. Plant 2018, 11, 995-998. [CrossRef]

101. Qin, L.; Li, J.; Wang, Q.; Xu, Z.; Sun, L.; Alariqi, M.; Manghwar, H.; Wang, G.; Li, B.; Ding, X.; et al. High Efficient and Precise Base Editing of $\mathrm{C} \bullet \mathrm{G}$ to T•A in the Allotetraploid Cotton (Gossypium hirsutum) Genome Using a Modified CRISPR/Cas9 System. Plant Biotechnol. J. 2020, 18, 45-56. [CrossRef]

102. Bortesi, L.; Zhu, C.; Zischewski, J.; Perez, L.; Bassié, L.; Nadi, R.; Forni, G.; Lade, S.B.; Soto, E.; Jin, X.; et al. Patterns of CRISPR/Cas9 activity in plants, animals and microbes. Plant Biotechnol. J. 2016, 14, 2203-2216. [CrossRef] 
103. Lee, K.; Zhang, Y.; Kleinstiver, B.P.; Guo, J.A.; Aryee, M.J.; Miller, J.; Malzahn, A.; Zarecor, S.; Lawrence-Dill, C.J.; Joung, J.K.; et al. Activities and specificities of CRISPR/Cas9 and Cas12a nucleases for targeted mutagenesis in maize. Plant Biotechnol. J. 2019, 17, 362-372. [CrossRef]

104. Zhang, Y.; Liang, Z.; Zong, Y.; Wang, Y.; Liu, J.; Chen, K.; Qiu, J.L.; Gao, C. Efficient and transgene-free genome editing in wheat through transient expression of CRISPR/Cas9 DNA or RNA. Nat. Commun. 2016. [CrossRef] [PubMed]

105. Jinek, M.; Chylinski, K.; Fonfara, I.; Hauer, M.; Doudna, J.A.; Charpentier, E. A programmable dual-RNA-guided DNA endonuclease in adaptive bacterial immunity. Science (80-. ). 2012, 337, 816-821. [CrossRef]

106. Wang, X.; Tu, M.; Wang, D.; Liu, J.; Li, Y.; Li, Z.; Wang, Y.; Wang, X. CRISPR/Cas9-mediated efficient targeted mutagenesis in grape in the first generation. Plant Biotechnol. J. 2018, 16, 844-855. [CrossRef] [PubMed]

107. Murugan, K.; Babu, K.; Sundaresan, R.; Rajan, R.; Sashital, D.G. The Revolution Continues: Newly Discovered Systems Expand the CRISPR-Cas Toolkit. Mol. Cell 2017, 68, 15-25. [CrossRef]

108. Ma, X.; Chen, X.; Jin, Y.; Ge, W.; Wang, W.; Kong, L.; Ji, J.; Guo, X.; Huang, J.; Feng, X.H.; et al. Small molecules promote CRISPR-Cpf1-mediated genome editing in human pluripotent stem cells. Nat. Commun. 2018. [CrossRef]

109. Riesenberg, S.; Maricic, T. Targeting repair pathways with small molecules increases precise genome editing in pluripotent stem cells. Nat. Commun. 2018. [CrossRef]

110. Yang, F.; Li, Y. The new generation tool for CRISPR genome editing: CRISPR/Cpf1. Sheng wu gong cheng xue bao= Chinese J. Biotechnol. 2017, 33, 361-371.

111. Maruyama, T.; Dougan, S.K.; Truttmann, M.C.; Bilate, A.M.; Ingram, J.R.; Ploegh, H.L. Corrigendum: Increasing the efficiency of precise genome editing with CRISPR-Cas9 by inhibition of nonhomologous end joining. Nat. Biotechnol. 2016, 34, 210. [CrossRef] [PubMed]

112. Ishii, T.; Araki, M. A future scenario of the global regulatory landscape regarding genome-edited crops. GM Crop. Food 2017, 8, 44-56. [CrossRef] [PubMed]

113. Wolt, J.D.; Wang, K.; Yang, B. The Regulatory Status of Genome-edited Crops. Plant Biotechnol. J. 2016, 14, 510-518. [CrossRef]

114. Callaway, E. CRISPR plants now subject to tough GM laws in European Union. Nature 2018, 560, 16. [CrossRef] [PubMed]

115. Sprink, T.; Eriksson, D.; Schiemann, J.; Hartung, F. Regulatory hurdles for genome editing: Process- vs. product-based approaches in different regulatory contexts. Plant Cell Rep. 2016, 35, 1493-1506. [CrossRef] [PubMed]

116. Slama-Ayed, O.; Bouhaouel, I.; Ayed, S.; De Buyser, J.; Picard, E.; Amara, H.S. Efficiency of three haplomethods in durum wheat (Triticum turgidum subsp. durum Desf.): Isolated microspore culture, gynogenesis and wheat $\times$ maize crosses. Czech J. Genet. Plant Breed. 2019, 55, 101-109. [CrossRef]

117. Chiurugwi, T.; Kemp, S.; Powell, W.; Hickey, L.T.; Powell, W. Speed breeding orphan crops. Theor. Appl. Genet. 2018. [CrossRef] [PubMed]

118. Weller, J.L.; Beauchamp, N.; Kerckhoffs, L.H.J.; Platten, J.D.; Reid, J.B. Interaction of phytochromes A and B in the control of de-etiolation and flowering in pea. Plant J. 2001, 26, 283-294. [CrossRef] [PubMed]

119. Giliberto, L.; Perrotta, G.; Pallara, P.; Weller, J.L.; Fraser, P.D.; Bramley, P.M.; Fiore, A.; Tavazza, M.; Giuliano, G. Manipulation of the blue light photoreceptor cryptochrome 2 in tomato affects vegetative development, flowering time, and fruit antioxidant content. Plant Physiol. 2005, 137, 199-208. [CrossRef]

120. Croser, J.S.; Pazos-Navarro, M.; Bennett, R.G.; Tschirren, S.; Edwards, K.; Erskine, W.; Creasy, R.; Ribalta, F.M. Time to flowering of temperate pulses in vivo and generation turnover in vivo-in vitro of narrow-leaf lupin accelerated by low red to far-red ratio and high intensity in the far-red region. Plant Cell. Tissue Organ Cult. 2016, 127, 591-599. [CrossRef]

121. Ribalta, F.M.; Pazos-Navarro, M.; Nelson, K.; Edwards, K.; Ross, J.J.; Bennett, R.G.; Munday, C.; Erskine, W.; Ochatt, S.J.; Croser, J.S. Precocious floral initiation and identification of exact timing of embryo physiological maturity facilitate germination of immature seeds to truncate the lifecycle of pea. Plant Growth Regul. 2017, 81, 345-353. [CrossRef]

122. Moe, R.; Heins, R. Control of plant morphogenesis and flowering by light quality and temperature. Acta Hortic. 1990, 81-90. [CrossRef]

123. Ausín, I.; Alonso-Blanco, C.; Martínez-Zapater, J.M. Environmental regulation of flowering. Int. J. Dev. Biol. 2005, 49, 689-705. [CrossRef] 
124. Ochatt, S.J.; Sangwan, R.S.; Marget, P.; Assoumou Ndong, Y.; Rancillac, M.; Perney, P. New approaches towards the shortening of generation cycles for faster breeding of protein legumes. Plant Breed. 2002, 121, 436-440. [CrossRef]

125. Ochatt, S.J.; Sangwan, R.S. In vitro shortening of generation time in Arabidopsis thaliana. Plant Cell. Tissue Organ Cult. 2008, 93, 133-137. [CrossRef]

126. Heuschele, D.J.; Case, A.; Smith, K.P. Evaluation of Fast Generation Cycling in Oat (Avena sativa). Cereal Res. Commun. 2019, 47, 626-635. [CrossRef]

127. Yao, Y.; Zhang, P.; Liu, H.; Lu, Z.; Yan, G. A fully in vitro protocol towards large scale production of recombinant inbred lines in wheat (Triticum aestivum L.). Plant Cell. Tissue Organ Cult. 2017, 128, 655-661. [CrossRef]

128. Sysoeva, M.I.; Markovskaya, E.F.; Shibaeva, T.G. Plants under continuous light: A review. Plant Stress 2010, 4, 5-17.

129. Achigan-Dako, E.G.; Sogbohossou, O.E.; Maundu, P. Current knowledge on Amaranthus spp.: research avenues for improved nutritional value and yield in leafy amaranths in sub-Saharan Africa. Euphytica 2014, 197, 303-317. [CrossRef]

130. Collard, B.C.Y.; Beredo, J.C.; Lenaerts, B.; Mendoza, R.; Santelices, R.; Lopena, V.; Verdeprado, H.; Raghavan, C.; Gregorio, G.B.; Vial, L.; et al. Revisiting rice breeding methods-evaluating the use of rapid generation advance (RGA) for routine rice breeding. Plant Prod. Sci. 2017, 20, 337-352. [CrossRef]

131. Wolter, F.; Schindele, P.; Puchta, H. Plant breeding at the speed of light: The power of CRISPR/Cas to generate directed genetic diversity at multiple sites. BMC Plant Biol. 2019, 19, 1-8. [CrossRef]

132. Bartley, G. Wheat (Triticum aestivum) residue management before growing soybean (Glycine max) in Manitoba. Master's Thesis, Department of Plant Science, University of Manitoba, Winnipeg, Manitoba, 2019.

133. Wilton, M. A Broad-Scale Characterization of Corn (Zea mays)-Soybean (Glycine max) Intercropping as a Sustainable-Intensive Cropping Practice. Ph.D. Thesis, University of Waterloo, Ontario, Canada, 2019.

134. Borlaug, N.E. Sixty-two years of fighting hunger: Personal recollections. Euphytica 2007, 157, 287-297. [CrossRef]

135. Ferrie, A.M.R.; Möllers, C. Haploids and doubled haploids in Brassica spp. for genetic and genomic research. Plant Cell Tissue Organ. Cult. 2011, 104, 375-386. [CrossRef]

136. Lübberstedt, T.; Frei, U.K. Application of doubled haploids for target gene fixation in backcross programmes of maize. Plant Breed. 2012, 131, 449-452. [CrossRef]

137. Dirks, R.; Van Dun, K.; De Snoo, C.B.; Van Den Berg, M.; Lelivelt, C.L.C.; Voermans, W.; Woudenberg, L.; De Wit, J.P.C.; Reinink, K.; Schut, J.W.; et al. Reverse breeding: A novel breeding approach based on engineered meiosis. Plant Biotechnol. J. 2009, 7, 837-845. [CrossRef] [PubMed]

138. Kebede, A.Z.; Dhillon, B.S.; Schipprack, W.; Araus, J.L.; Bänziger, M.; Semagn, K.; Alvarado, G.; Melchinger, A.E. Effect of source germplasm and season on the in vivo haploid induction rate in tropical maize. Euphytica 2011, 180, 219-226. [CrossRef]

139. Castillo, A.M.; Cistué, L.; Vallés, M.P.; Soriano, M. Chromosome Doubling in Monocots. In Advances in Haploid Production in Higher Plants; Springer: New York, NY, USA, 2009; pp. 329-338.

140. Prigge, V.; Melchinger, A.E. Production of haploids and doubled haploids in maize. In Plant Cell Culture Protocols; Springer: New York, NY, USA, 2012; pp. 161-172.

141. Raju, S.K.K.; Shao, M.R.; Sanchez, R.; Xu, Y.Z.; Sandhu, A.; Graef, G.; Mackenzie, S. An epigenetic breeding system in soybean for increased yield and stability. Plant Biotechnol. J. 2018, 16, 1836-1847. [CrossRef]

142. Halpin, C. Gene stacking in transgenic plants-The challenge for 21st century plant biotechnology. Plant Biotechnol. J. 2005, 3, 141-155. [CrossRef]

143. Belhaj, K.; Chaparro-Garcia, A.; Kamoun, S.; Nekrasov, V. Plant genome editing made easy: Targeted mutagenesis in model and crop plants using the CRISPR/Cas system. Plant Methods 2013. [CrossRef]

144. Low, J.W.; Mwanga, R.O.M.; Andrade, M.; Carey, E.; Ball, A.-M. Tackling vitamin A deficiency with biofortified sweetpotato in sub-Saharan Africa. Glob. Food Sec. 2017, 14, 23-30. [CrossRef]

145. Møller, I.S.; Gilliham, M.; Jha, D.; Mayo, G.M.; Roy, S.J.; Coates, J.C.; Haseloff, J.; Tester, M. Shoot Na+ exclusion and increased salinity tolerance engineered by cell type-specific alteration of $\mathrm{Na}+$ transport in Arabidopsis. Plant Cell 2009, 21, 2163-2178. [CrossRef]

146. Singh, N.K.; Gupta, D.K.; Jayaswal, P.K.; Mahato, A.K.; Dutta, S.; Singh, S.; Bhutani, S.; Dogra, V.; Singh, B.P.; Kumawat, G.; et al. The first draft of the pigeonpea genome sequence. J. Plant Biochem. Biotechnol. 2012, 21, 98-112. [CrossRef] 
147. Jackson, S.A. Rice: The First Crop Genome. Rice 2016, 9. [CrossRef]

148. Egan, A.N.; Schlueter, J.; Spooner, D.M. Applications of next-generation sequencing in plant biology. Am. J. Bot. 2012, 99, 175-185. [CrossRef] [PubMed]

149. Bernier, G.; Périlleux, C. A physiological overview of the genetics of flowering time control. Plant Biotechnol. J. 2005, 3, 3-16. [CrossRef] [PubMed]

150. Kondić-špika, A.; Kobiljski, B. Biotechnology in Modern Breeding and Agriculture. In Proceedings of the International Conference on BioScience: Biotechnology and Biodiversity-Step in the Future. The Fourth Joint UNS-PSU Conference, Novi Sad, Serbia, 18-20 June 2012.

151. Liang, Z.; Chen, K.; Li, T.; Zhang, Y.; Wang, Y.; Zhao, Q.; Liu, J.; Zhang, H.; Liu, C.; Ran, Y.; et al. Efficient DNA-free genome editing of bread wheat using CRISPR/Cas9 ribonucleoprotein complexes. Nat. Commun. 2017. [CrossRef] [PubMed]

152. Hedden, P. The genes of the Green Revolution. TRENDS Genet. 2003, 19, 5-9. [CrossRef]

153. Knoch, D.; Abbadi, A.; Grandke, F.; Meyer, R.C.; Samans, B.; Werner, C.R.; Snowdon, R.J.; Altmann, T. Strong temporal dynamics of QTL action on plant growth progression revealed through high-throughput phenotyping in canola. Plant Biotechnol. J. 2020, 18, 68-82. [CrossRef]

154. Yin, K.; Gao, C.; Qiu, J.L. Progress and prospects in plant genome editing. Nat. Plants 2017, 3, 1-6. [CrossRef]

155. Waltz, E. CRISPR-Edited Crops Free to Enter Market, Skip Regulation; Nature Publishing Group: Berlin, Germany, 2016.

156. Eş, I.; Gavahian, M.; Marti-Quijal, F.J.; Lorenzo, J.M.; Mousavi Khaneghah, A.; Tsatsanis, C.; Kampranis, S.C.; Barba, F.J. The application of the CRISPR-Cas9 genome editing machinery in food and agricultural science: Current status, future perspectives, and associated challenges. Biotechnol. Adv. 2019. [CrossRef]

157. Xu, R.; Yang, Y.; Qin, R.; Li, H.; Qiu, C.; Li, L.; Wei, P.; Yang, J. Rapid improvement of grain weight via highly efficient CRISPR/Cas9-mediated multiplex genome editing in rice. J. Genet. Genomics 2016, 43, 529-532. [CrossRef]

158. Zhang, J.; Zhang, H.; Botella, J.R.; Zhu, J. Generation of new glutinous rice by CRISPR/Cas9-targeted mutagenesis of the Waxy gene in elite rice varieties. J. Integr. Plant Biol. 2018, 60, 369-375. [CrossRef]

159. Nekrasov, V.; Wang, C.; Win, J.; Lanz, C.; Weigel, D.; Kamoun, S. Rapid generation of a transgene-free powdery mildew resistant tomato by genome deletion. Sci. Rep. 2017. [CrossRef]

160. Wang, F.; Wang, C.; Liu, P.; Lei, C.; Hao, W.; Gao, Y.; Liu, Y.G.; Zhao, K. Enhanced rice blast resistance by CRISPR/ Cas9-Targeted mutagenesis of the ERF transcription factor gene OsERF922. PLoS ONE 2016. [CrossRef] [PubMed]

161. Kumar, M.; Aslam, M.; Manisha, Y.; Manoj, N. An Update on Genetic Modification of Chickpea for Increased Yield and Stress Tolerance. Mol. Biotechnol. 2018, 60, 651-663. [CrossRef] [PubMed]

162. Domoney, C.; Knox, M.; Moreau, C.; Ambrose, M.; Palmer, S.; Smith, P.; Christodoulou, V.; Isaac, P.G.; Hegarty, M.; Blackmore, T.; et al. Exploiting a fast neutron mutant genetic resource in Pisum sativum (pea) for functional genomics. Funct. Plant Biol. 2013, 40, 1261. [CrossRef]

163. Raman, H.; Raman, R.; Kilian, A.; Detering, F.; Carling, J.; Coombes, N.; Diffey, S.; Kadkol, G.; Edwards, D.; Mccully, M.; et al. Genome-Wide Delineation of Natural Variation for Pod Shatter Resistance in Brassica napus. PLoS ONE 2014, 9, e101673. [CrossRef] [PubMed]

164. Panigrahi, R.; Kariali, E.; Panda, B.; Lafarge, T.; Mohapatra, P.K. Controlling the trade-off between spikelet number and grain filling; the hierarchy of starch synthesis in spikelets of rice panicle in relation to hormone dynamics. Funct. Plant Biol. 2019, 46, 507-523. [CrossRef] [PubMed]

165. Witcombe, J.R.; Gyawali, S.; Subedi, M.; Virk, D.S.; Joshi, K.D. Plant breeding can be made more efficient by having fewer, better crosses. BMC Plant Biol. 2013, 13, 22. [CrossRef]

166. Basnet, B.R.; Crossa, J.; Dreisigacker, S.; Perez-Rodriguez, P.; Manes, Y.; Singh, R.P.; Rosyara, U.R.; Camarillo-Castillo, F; Murua, M. Hybrid Wheat Prediction Using Genomic, Pedigree, and Environmental Covariables Interaction Models. Plant Genome 2019, 12. [CrossRef]

167. Xu, Y.; Babu, R.; Skinner, D.J.; Vivek, B.S.; Crouch, J.H. Maize Mutant opaque2 and the Improvement of Protein Quality through Conventional and Molecular Approaches. In Proceedings of the International Symposium on Induced Mutation in Plants, Vienna, Austria, 2-15 August 2008.

168. Shuwen, S.; Lianghong, L.; Jiangsheng, W.; Yongming, Z. In vitro screening stem rot resistant ( tolerant ) materials in Brassica napus L. Chin. J. Oil Crop Sci. 2003, 25, 5-8.

169. Pathirana, R. Plant mutation breeding in agriculture. Plant Sci. Rev. 2011, 107-126. [CrossRef] 
170. International Atomic Energy Agency. Proceedings of the International Symposium on Plant Mutation Breeding and Biotechnology, Vienna, Austria, 27-31 August 2018.

171. Ceballos, H.; Sanchez, T.; Denyer, K.; Tofino, A.P.; Rosero, E.A.; Dufour, D.; Smith, A.; Morante, N.; Perez, J.C.; Fahy, B. Induction and identification of a small-granule, high-amylose mutant in cassava (Manihot esculenta Crantz). J. Agric. Food Chem. 2008, 56, 7215-7222. [CrossRef]

172. Hamid, M.A.; Azad, M.A.K.; Howelider, M.A.R. Development of Three Groundnut Varieties with Improved Quantitative and Qualitative Traits through Induced Mutation. Plant Mutat. reports 2006, 1, 14-16.

173. Newell-McGloughlin, M. Nutritionally improved agricultural crops. Plant Physiol. 2008, 147, 939-953. [CrossRef] [PubMed]

174. Dunwell, J.M. Transgenic approaches to crop improvement. J. Exp. Bot. 2000, 51, 487-496. [CrossRef] [PubMed]

175. Toojinda, T.; Baird, E.; Booth, A.; Broers, L.; Hayes, P.; Powell, W.; Thomas, W.; Vivar, H.; Young, G. Introgression of quantitative trait loci (QTLs) determining stripe rust resistance in barley: An example of marker-assisted line development. Theor. Appl. Genet. 1998, 96, 123-131. [CrossRef]

176. Gimode, W.; Clevenger, J.; McGregor, C. Fine-mapping of a major quantitative trait locus Qdff3-1 controlling flowering time in watermelon. Mol. Breed. 2020, 40, 1-12. [CrossRef]

177. Joshi, S.G.; Schaart, J.G.; Groenwold, R.; Jacobsen, E.; Schouten, H.J.; Krens, F.A. Functional analysis and expression profiling of HcrVf1 and HcrVf2 for development of scab resistant cisgenic and intragenic apples. Plant Mol. Biol. 2011, 75, 579-591. [CrossRef]

178. Würdig, J.; Flachowsky, H.; Saß, A.; Peil, A.; Hanke, M.V. Improving resistance of different apple cultivars using the Rvi6 scab resistance gene in a cisgenic approach based on the Flp/FRT recombinase system. Mol. Breed. 2015, 35. [CrossRef]

179. Holme, I.B.; Wendt, T.; Holm, P.B. Intragenesis and cisgenesis as alternatives to transgenic crop development. Plant Biotechnol. J. 2013, 11, 395-407. [CrossRef]

180. Gadaleta, A.; Giancaspro, A.; Blechl, A.E.; Blanco, A. A transgenic durum wheat line that is free of marker genes and expresses 1Dy10. J. Cereal Sci. 2008, 48, 439-445. [CrossRef]

181. Cardi, T. Cisgenesis and genome editing: Combining concepts and efforts for a smarter use of genetic resources in crop breeding. Plant Breed. 2016, 135, 139-147. [CrossRef]

182. Jo, K.-R.; Kim, C.-J.; Kim, S.-J.; Kim, T.-Y.; Bergervoet, M.; Jongsma, M.A.; Visser, R.G.F.; Jacobsen, E.; Vossen, J.H. Development of late blight resistant potatoes by cisgene stacking. BMC Biotechnol. 2014, 14, 50. [CrossRef] [PubMed]

183. Schaart, J.G. Towards Consumer-Friendly Cisgenic Strawberries which are Less Susceptible to Botrytis Cinerea; Research Gate: Berlin, Germany, 2004; ISBN 908504104X.

184. Sawai, S.; Ohyama, K.; Yasumoto, S.; Seki, H.; Sakuma, T.; Yamamoto, T.; Takebayashi, Y.; Kojima, M.; Sakakibara, H.; Aoki, T.; et al. Sterol side chain reductase 2 is a key enzyme in the biosynthesis of cholesterol, the common precursor of toxic steroidal glycoalkaloids in potato. Plant Cell 2014, 26, 3763-3774. [CrossRef] [PubMed]

185. Luo, M.; Li, H.; Chakraborty, S.; Morbitzer, R.; Rinaldo, A.; Upadhyaya, N.; Bhatt, D.; Louis, S.; Richardson, T.; Lahaye, T.; et al. Efficient TALEN mediated gene editing in wheat. Plant Biotechnol. J. 2019, 17, 2026-2028. [CrossRef] [PubMed]

186. Zhou, J.; Peng, Z.; Long, J.; Sosso, D.; Liu, B.; Eom, J.-S.; Huang, S.; Liu, S.; Vera Cruz, C.; Frommer, W.B.; et al. Gene targeting by the TAL effector PthXo2 reveals cryptic resistance gene for bacterial blight of rice. Plant $J$. 2015, 82, 632-643. [CrossRef] [PubMed]

187. Svitashev, S.; Young, J.K.; Schwartz, C.; Gao, H.; Falco, S.C.; Cigan, A.M. Targeted Mutagenesis, Precise Gene Editing, and Site-Specific Gene Insertion in Maize Using Cas9 and Guide RNA. Plant Physiol. 2015, 169, 931-945. [CrossRef] [PubMed]

188. Zhou, X.; Jacobs, T.B.; Xue, L.-J.; Harding, S.A.; Tsai, C.-J. Exploiting SNPs for biallelic CRISPR mutations in the outcrossing woody perennial Populus reveals 4-coumarate:CoA ligase specificity and redundancy. New Phytol. 2015, 208, 298-301. [CrossRef] [PubMed]

189. Brooks, C.; Nekrasov, V.; Lippman, Z.B.; Van Eck, J. Efficient gene editing in tomato in the first generation using the clustered regularly interspaced short palindromic repeats/CRISPR-associated9 system. Plant Physiol. 2014, 166, 1292-1297. [CrossRef]

190. Li, Z.; Liu, Z.-B.; Xing, A.; Moon, B.P.; Koellhoffer, J.P.; Huang, L.; Ward, R.T.; Clifton, E.; Falco, S.C.; Cigan, A.M. Cas9-Guide RNA Directed Genome Editing in Soybean. Plant Physiol. 2015, 169, 960-970. [CrossRef] 
191. Zhao, X.; Meng, Z.; Wang, Y.; Chen, W.; Sun, C.; Cui, B.; Cui, J.; Yu, M.; Zeng, Z.; Guo, S.; et al. Pollen magnetofection for genetic modification with magnetic nanoparticles as gene carriers. Nat. Plants 2017, 3, 956-964. [CrossRef]

192. Han, J.; Guo, B.; Guo, Y.; Zhang, B.; Wang, X.; Qiu, L.-J. Creation of Early Flowering Germplasm of Soybean by CRISPR/Cas9 Technology. Front. Plant Sci. 2019, 10, 1-10. [CrossRef]

193. Sánchez-León, S.; Gil-Humanes, J.; Ozuna, C.V.; Giménez, M.J.; Sousa, C.; Voytas, D.F.; Barro, F. Low-gluten, nontransgenic wheat engineered with CRISPR/Cas9. Plant Biotechnol. J. 2018, 16, 902-910. [CrossRef] [PubMed]

194. Farhat, S.; Jain, N.; Singh, N.; Sreevathsa, R.; Das, P.K.; Rai, R.; Yadav, S.; Kumar, P.; Sarkar, A.; Jain, A. CRISPR-cas 9 directed genome engineering for enhancing salt stress tolerance in rice. In Proceedings of the Seminars in Cell E Developmental Biology; Elsevier: Amsterdam, The Netherlands, 2019.

195. Zaman, Q.U.; Chu, W.; Hao, M.; Shi, Y.; Sun, M.; Sang, S.-F.; Mei, D.; Cheng, H.; Liu, J.; Li, C. CRISPR/Cas9-Mediated Multiplex Genome Editing of JAGGED Gene in Brassica napus L. Biomolecules 2019, 9, 725. [CrossRef] [PubMed]

196. Veillet, F.; Perrot, L.; Chauvin, L.; Kermarrec, M.-P.; Guyon-Debast, A.; Chauvin, J.-E.; Nogué, F.; Mazier, M. Transgene-free genome editing in tomato and potato plants using agrobacterium-mediated delivery of a CRISPR/Cas9 cytidine base editor. Int. J. Mol. Sci. 2019, 20, 402. [CrossRef] [PubMed]

197. Hsu, C.-T.; Cheng, Y.-J.; Yuan, Y.-H.; Hung, W.-F.; Cheng, Q.-W.; Wu, F.-H.; Lee, L.-Y.; Gelvin, S.B.; Lin, C.-S. Application of Cas12a and nCas9-activation-induced cytidine deaminase for genome editing and as a non-sexual strategy to generate homozygous/multiplex edited plants in the allotetraploid genome of tobacco. Plant Mol. Biol. 2019. [CrossRef]

198. Yin, X.; Anand, A.; Quick, P.; Bandyopadhyay, A. Editing a Stomatal Developmental Gene in Rice with CRISPR/Cpf1. In Plant Genome Editing with CRISPR Systems; Springer: New York, NY, USA, 2019; pp. $257-268$.

199. Malzahn, A.A.; Tang, X.; Lee, K.; Ren, Q.; Sretenovic, S.; Zhang, Y.; Chen, H.; Kang, M.; Bao, Y.; Zheng, X.; et al. Application of CRISPR-Cas12a temperature sensitivity for improved genome editing in rice, maize, and Arabidopsis. BMC Biol. 2019, 17, 1-14. [CrossRef]

200. Oconnor, D.; Wright, G.; George, D.; Hunter, M. Development and Application of Speed Breeding Technologies in a Commercial Peanut Breeding Program Development and Application of Speed Breeding Technologies in a Commercial Peanut Breeding Program. Peanut Sci. 2013, 40, 107-114. [CrossRef]

201. Riaz, A. Unlocking new sources of adult plant resistance to wheat leaf rust. Ph.D. Thesis, The University of Queensland, Queensland, Australia, 2018; pp. 1-241.

202. Wang, X.; Xuan, H.; Evers, B.; Shrestha, S.; Pless, R.; Poland, J. High-throughput phenotyping with deep learning gives insight into the genetic architecture of flowering time in wheat. bioRxiv 2019, 527911.

203. Danzi, D.; Briglia, N.; Petrozza, A.; Summerer, S.; Povero, G.; Stivaletta, A.; Cellini, F.; Pignone, D.; de Paola, D.; Janni, M. Can high throughput phenotyping help food security in the mediterranean area? Front. Plant. Sci. 2019, 10, 15.

(C) 2020 by the authors. Licensee MDPI, Basel, Switzerland. This article is an open access article distributed under the terms and conditions of the Creative Commons Attribution (CC BY) license (http://creativecommons.org/licenses/by/4.0/). 